Provided for non-commercial research and education use. Not for reproduction, distribution or commercial use.

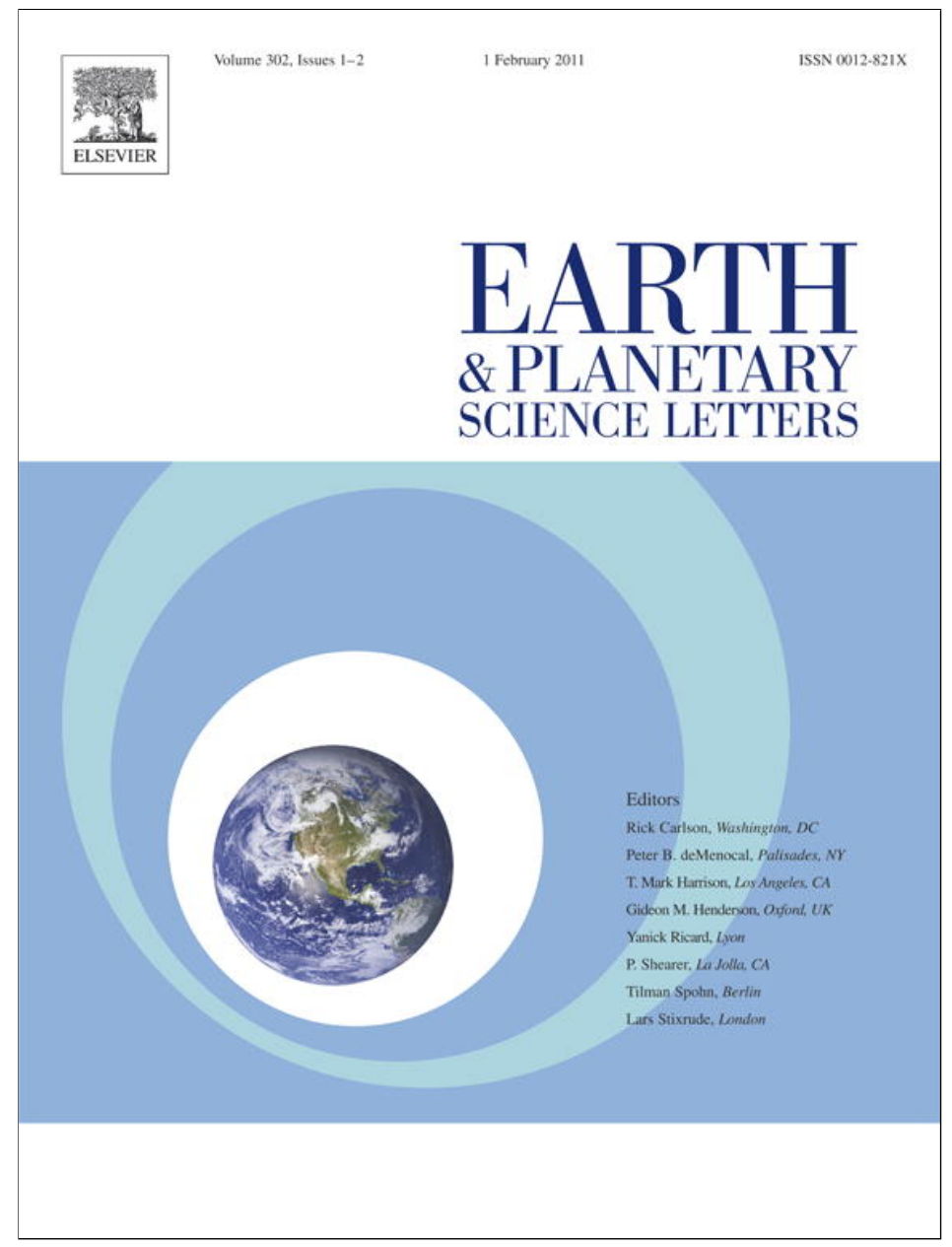

This article appeared in a journal published by Elsevier. The attached copy is furnished to the author for internal non-commercial research and education use, including for instruction at the authors institution and sharing with colleagues.

Other uses, including reproduction and distribution, or selling or licensing copies, or posting to personal, institutional or third party websites are prohibited.

In most cases authors are permitted to post their version of the article (e.g. in Word or Tex form) to their personal website or institutional repository. Authors requiring further information regarding Elsevier's archiving and manuscript policies are encouraged to visit:

http://www.elsevier.com/copyright 


\title{
Mineralogical and chemical variability of fluvial sediments 2. Suspended-load silt (Ganga-Brahmaputra, Bangladesh)
}

\author{
Eduardo Garzanti a,*, Sergio Andó a,1, Christian France-Lanord ${ }^{\mathrm{b}, 2}$, Paolo Censi ${ }^{\mathrm{c}, 3}$, Pietro Vignola ${ }^{\mathrm{d}, 4}$, \\ Valier Galy ${ }^{\mathrm{b}, 5}$, Maarten Lupker ${ }^{\mathrm{b}, 2}$ \\ a Laboratorio di Petrografia del Sedimentario, Dipartimento di Scienze Geologiche e Geotecnologie, Università di Milano-Bicocca, 20126 Milano, Italy \\ ${ }^{\mathrm{b}}$ Centre de Recherches Pétrographiques et Géochimiques, BP 20, 54501 Vandoeuvre-lès-Nancy, France \\ c Dipartimento CFTA, Università di Palermo, 90123 Palermo, Italy \\ d Consiglio Nazionale delle Ricerche, Istituto per la Dinamica dei Processi Ambientali, 20133 Milano, Italy
}

\section{A R T I C L E I N F O}

\section{Article history:}

Received 22 June 2010

Received in revised form 25 November 2010

Accepted 30 November 2010

Available online 24 December 2010

Editor: P. DeMenocal

\section{Keywords:}

silt mineralogy

settling equivalence

suspension sorting

Raman spectroscopy

REE geochemistry

weathering indices

\begin{abstract}
A B S T R A C T
Sediments carried in suspension represent a fundamental part of fluvial transport. Nonetheless, largely because of technical problems, they have been hitherto widely neglected in provenance studies. In order to determine with maximum possible precision the mineralogy of suspended load collected in vertical profiles from water surface to channel bottom of Rivers Ganga and Brahmaputra, we combined Raman spectroscopy with traditional heavymineral and X-ray diffraction analyses, carried out separately on low-density and dense fractions of all significant size classes in each sample (multiple-window approach). Suspended load resulted to be a ternary mixture of dominant silt enriched in phyllosilicates, subordinate clay largely derived from weathered floodplains, and sand mainly produced by physical erosion and mechanical grinding during transport in Himalayan streams. Sediment concentration and grain size increase steadily with water depth. Whereas absolute concentration of clay associated with Fe-oxyhydroxides and organic matter is almost depth-invariant, regular mineralogical and consequently chemical changes from shallow to deep load result from marked increase of faster-settling, coarser, denser, or more spherical grains toward the bed. Such steady intersample compositional variability can be modeled as a mixture of clay, silt and sand modes with distinct mineralogical and chemical composition. With classical formulas describing sediment transport by turbulent diffusion, absolute and relative concentrations can be predicted at any depth for each textural mode and each detrital component. Based on assumptions on average chemistry of detrital minerals and empirical formulas to calculate their settling velocities, the suspension-sorting model successfully reproduces mineralogy and chemistry of suspended load at different depths. Principal outputs include assessment of contributions by each detrital mineral to the chemical budget, and calibration of dense minerals too rare to be precisely estimated by optical or Raman analysis but crucial in both detrital-geochronology and settling-equivalence studies. Hydrodynamic conditions during monsoonal discharge could also be evaluated. Understanding compositional variability of suspended load is a fundamental pre-requisite to correctly interpret mineralogical and geochemical data in provenance analysis of modern and ancient sedimentary deposits, to accurately assess weathering processes, sediment fluxes and erosion patterns, and to unambiguously evaluate the effects of anthropogenic modifications on the natural environment.
\end{abstract}

(C) 2010 Elsevier B.V. All rights reserved.

\section{Introduction}

\footnotetext{
* Corresponding author. Tel.: +3902 64482088; fax: +390264482073.

E-mail addresses: eduardo.garzanti@unimib.it (E. Garzanti), sergio.ando@unimib.it (S. Andó), cfl@crpg.cnrs-nancy.fr (C. France-Lanord), censi@unipa.it (P. Censi), pietro.vignola@idpa.cnr.it (P. Vignola),vgaly@whoi.edu (V. Galy), mlupker@crpg.cnrs-nancy.fr (M. Lupker).

1 Tel.: +3902 64482097; fax: +3902 64482073.

2 Tel.: +33 383 594220; fax: +33 383511798

3 Tel.: +39 091 23861638; fax: +39 091 347990. Also at IAMC-CNR UOS di Capo Granitola, 91026 Campobello di Mazara (Trapani), Italy.

${ }^{4}$ Tel.: +3902 50315592; fax: +390250315597.

${ }^{5}$ Now at Woods Hole Oceanographic Institution, 360 Woods Hole Road, Woods Hole, MA 02543, USA.
}

"Rivers like the Ganga and the Brahmaputra shroud this window with a curtain of silt: a flowing stream of suspended matter in which visibility does not extend beyond an arm's length. As if to address this, the Gangetic dolphin habitually swims on its side, with one of its lateral fins trailing the bottom, as though to anchor itself in its darkened world by keeping a hold on its floor." Amitav Gosh, The Hungry Tide, p.46

Silt carried in suspension represents most of the sediment flux in rivers (Hay, 1998; Milliman and Meade, 1983), and the predominant 
grain size in large deltas and submarine fans (Allison et al., 2003; Curray et al., 2003). Provenance studies, however, are traditionally focused on compositional analysis of sand (Dickinson and Suczek, 1979; Garzanti et al., 2007a; Ingersoll, 1990; Potter, 1978; Valloni and Maynard, 1981; Zuffa, 1985), which is much easier to treat in the laboratory and to analyse with standard petrographic techniques. As a consequence, quantitative estimates of sediment yields and erosion rates are often based on the undemonstrated assumption that bedload and suspended load have the same provenance (e.g., Garzanti et al. 2007b).

Compositional information on silt is essential to carry out an unbiased study of fluvial to turbiditic transport and deposition of sediment (Cullers, 1988; Yokohama et al., 1990). It is thus fundamental to implement the appropriate techniques to obtain reliable quantitative mineralogical data on silt-sized sediments (Poppe and Commeau, 1996; Totten and Hanan, 2007). Given the dominance of sedimentary rock outcrops, at least two-thirds of which are mudrocks (Blatt and Jones, 1975), enhanced power to investigate provenance of silt will allow us to reconstruct in a far more complete way geodynamic sceneries of the past. Moreover, mud is less permeable than sand, and consequently less affected by intrastratal dissolution and diagenetic processes in general. Ancient siltstones are consequently prone to preserve their original detrital suite more faithfully than interlayered sandstones (Blatt and Sutherland, 1969). Nevertheless, and in spite of authoritative recommendations (Blatt, 1985), provenance analysis of silt has progressed little since Henry Clifton Sorby founded sedimentary petrography over a century ago. Quantitative mineralogical analysis of silt involves in fact considerable practical problems, including difficulties in physical separation and identification of tiny grains under the microscope. Xray diffraction techniques are widely used, but data become rapidly uncertain with increasing number of significant detrital phases (Schieber and Zimmerle, 1998).
In the present article, companion to a study dedicated to bedload sand (Garzanti et al., 2010), we thoroughly investigate physical and chemical processes affecting sediment carried in suspension at various water depths in Rivers Ganga and Brahmaputra. Their estuary in Bangladesh represents the largest single entry point of detritus in the world oceans, which through the Neogene has fed the huge turbidite fan expanding on Bengal Sea floors (Fig. 1; France-Lanord et al., 1993; Goodbred and Kuehl, 2000). Our work is based on a continuing research project carried out throughout the last decade by CNRS-CRPG researchers (Galy and France-Lanord, 1999; Galy et al., 2007; Singh and France-Lanord, 2002).

In order to identify with full confidence silt-sized grains, we combined a variety of methods, including the innovative Raman spectroscopy technique coupled with classical heavy-mineral and X-ray powder-diffraction analyses (XRD), carried out in different laboratories and separately on low-density and dense fractions of each sample to reduce the number of phases and improve the reliability of obtained results. The principal novelty of our approach consists in the systematic integration of mineralogical, geochemical, textural, and sedimentconcentration data in order to assess quantitative relationships among compositional variables for each sample and each grain-size class of each sample. By evaluating the distribution of diverse chemical elements in different minerals, we could investigate hydrodynamic processes that control segregation of detrital grains through the water column (Vanoni, 2006), and thus mathematically predict mineralogical and chemical composition at various depths in the Ganga-Brahmaputra sedimentary system.

Such a detailed approach is of crucial importance to make accurate provenance diagnoses and sediment budgets for modern and ancient deposits, and to correctly unravel the innumerable pieces of geological information stored in sedimentary archives, from the alluvial plain to the deep-sea.

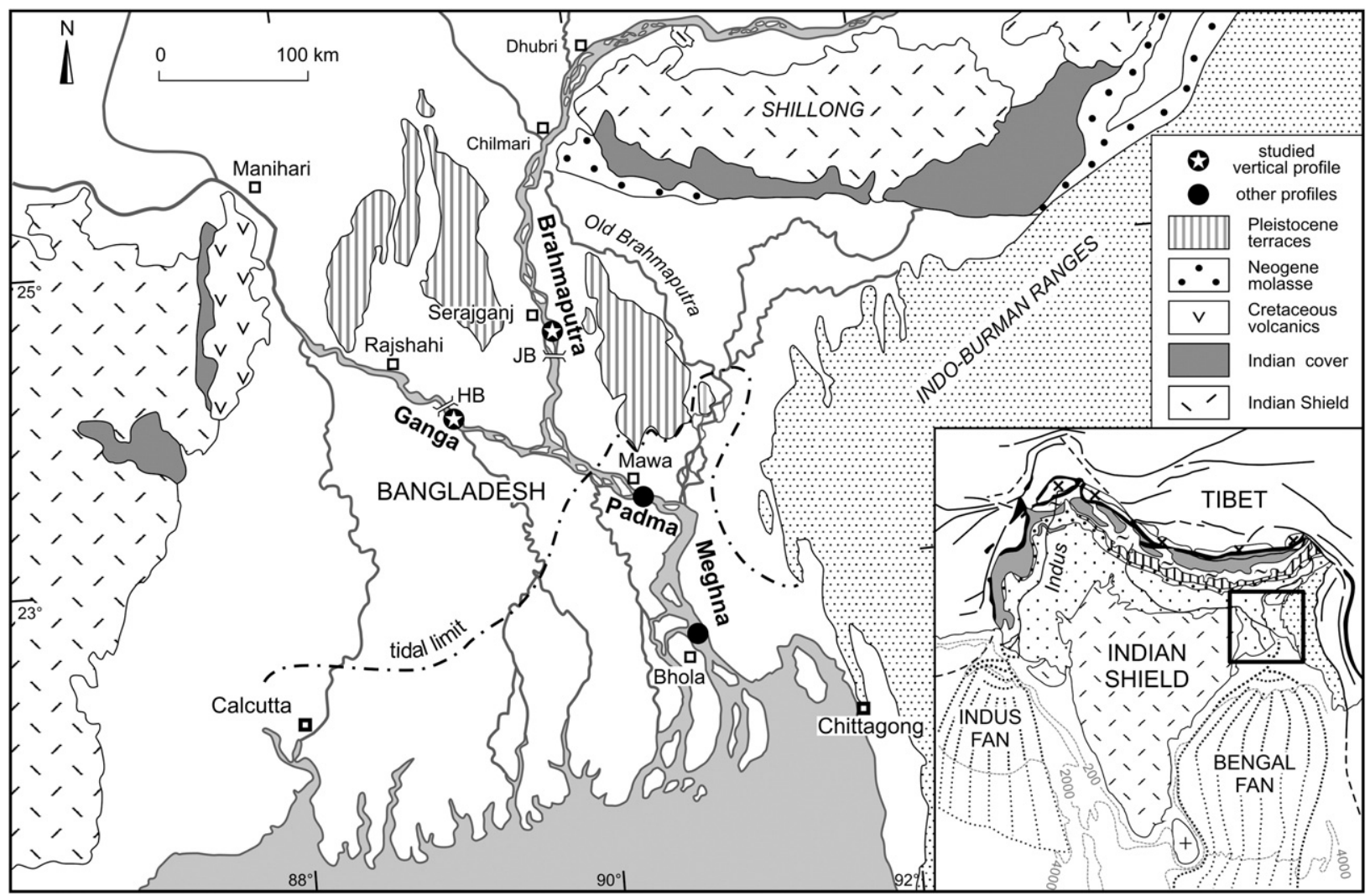

Fig. 1. The Ganga-Brahmaputra fluviodeltaic system in Bangladesh. Main geological features and location of studied vertical profiles are indicated. HB= Hardinge Bridge; $\mathrm{JB}=$ Jamuna Bridge 


\section{Methods}

Suspended load was collected during the full monsoon season (July 2004, July 2005, and August 2007), when the bulk of water and sediment discharge takes place, in Rivers Ganga (downstream of Hardinge Bridge) and Brahmaputra (Sirajganj to Jamuna Bridge), and in the Padma (near Mawa) and Meghna estuary (near Bhola; Fig. 1). Samples were taken at 0 to $24 \mathrm{~m}$ depth from a boat, returning each time approximately on the same GPS site in order to construct ideally vertical profiles from water surface down to the river bed. Each year, one profile was made in the main Ganga, Brahmaputra and PadmaMeghna channel where velocity is highest. Occasionally, profiles were also made in low-velocity zones close to the bank to obtain a more complete representation of the river section.

\subsection{Multiple-window and multi-technique mineralogical analyses}

Mineralogical analyses of silt were carried out separately for all significant size classes of 19 samples (multiple-window method; Garzanti et al., 2009), split by wet sieving at 0.5 or $1 \phi$ intervals and separated into dense $\left(>2.90 \mathrm{~g} / \mathrm{cm}^{3}\right)$ and low-density $\left(<2.90 \mathrm{~g} / \mathrm{cm}^{3}\right)$ fractions. Optical heavy-mineral analyses ( 75 slides, 12,437 transparent grains overall) were coupled with XRD/Rietveld analyses of dense and low-density fractions of all significant size classes of 5 Ganga, Brahmaputra, and Meghna surface-load samples and a Ganga vertical profile (3 samples). For two complete Ganga (6 samples) and Brahmaputra (5 samples) vertical profiles, accurate quantitative data were obtained by coupling Raman spectroscopy (22 slides, 2327 grains overall) and heavy-mineral analyses on all size classes $>10 \mu \mathrm{m}$. The $<10 \mu \mathrm{m}$ class, not easily handled by Raman or optical techniques, was analysed in bulk by XRD/Rietveld, whereas heavy-mineral analyses were carried out on the dense fraction separated by centrifuging after removing clay. The light fraction of the $<10 \mu \mathrm{m}$ class was tentatively analysed under the microscope; although optical discrimination of finesilt-sized quartz, feldspars and white mica proved to be exceedingly difficult, useful information was obtained to validate XRD/Rietveld data. Depending on volume percentage of heavy minerals (HMC index; Garzanti and Andò, 2007), suites are described as "extremely poor" $(\mathrm{HMC}<0.1)$, "very poor" $(0.1 \leq \mathrm{HMC}<0.5)$, "poor" $(0.5 \leq \mathrm{HMC}<1)$, "moderately poor" $(1 \leq \mathrm{HMC}<2)$, "moderately rich" $(2 \leq \mathrm{HMC}<5)$, or "rich" $(5 \leq \mathrm{HMC}<10)$.

XRD analyses on 16 additional bulk-sediment samples from a complete vertical profile for each river branch were carried out by both traditional methods (Moore and Reynolds, 1989) and Rietveld

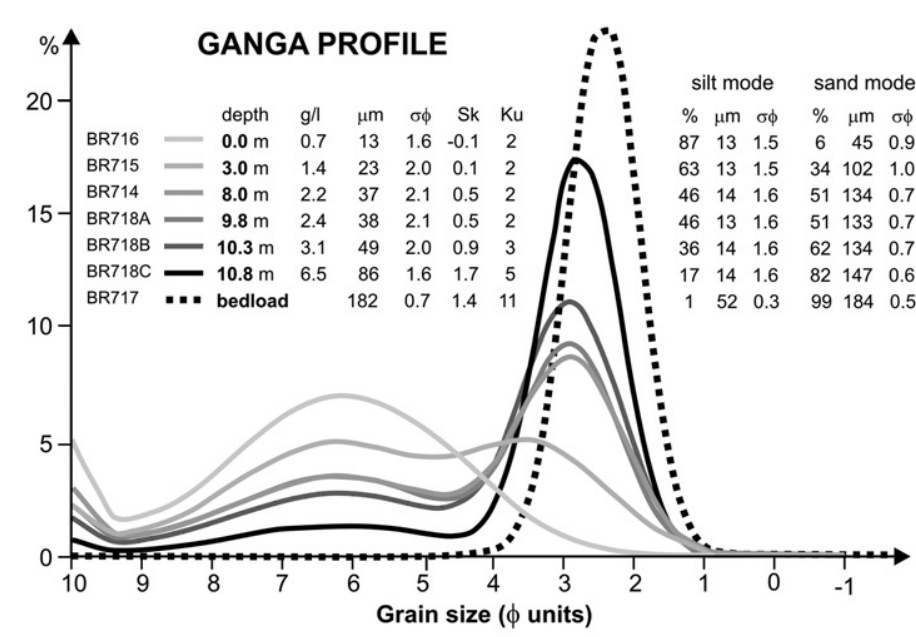

refinement (Webster et al., 2003). Blind tests were performed on ternary mixtures of quartz, K-feldspar and albite in various proportions to check the accuracy of the refinement process. As a further test, we collected XRD patterns at ESRF synchrotron (Grenoble).

\subsection{Chemical analyses and comparison with mineralogical modes}

Major and trace element concentrations on bulk samples were measured by ICP-AES and ICP-MS after lithium metaborate fusion at CRPG-Nancy (for full information on analytical procedures, geostandards used, and precision for various elements see Govindaraju and Mevelle (1987); Carignan et al. (2001); http://helium.crpg.cnrs-nancy. fr/SARM/index.html). Distinct size classes extracted by settling technique were analysed for Ganga samples BR522 $(<2,2-20,20-50$, and $50-200 \mu \mathrm{m})$, BGP5 $(<0.1$ and $<2 \mu \mathrm{m})$, and BGP6 $(<2 \mu \mathrm{m})$. Chemical composition is discussed with reference to estimated element concentration in the upper continental crust (UCC; Hu and Gao, 2008; McLennan, 2001; Taylor and McLennan, 1995) and standard shale (PAAS; Taylor and McLennan, 1985). REE data were normalized to CI carbonaceous chondrites (McDonough and Sun, 1995).

Among the numerous indices proposed to estimate chemical weathering (Duzgoren-Aydin et al., 2002), we chose to use the Chemical Index of Alteration (CIA; Nesbitt and Young, 1982) and the Weathering Index (WIP; Parker, 1970), calculated using molecular proportions of mobile alkali and alkaline earth metals corrected for $\mathrm{Ca}$ in apatite and carbonates. The CIA is widely interpreted as a measure of the extent of conversion of feldspar to clays such as kaolinite, whereas the WIP is most appropriate for heterogeneous sources including metamorphic rocks (Borges and Huh, 2007; Price and Velbel, 2003). Increasing alteration is indicated by increasing CIA and decreasing WIP.

We systematically converted mineralogical modes into chemical modes to compare real-chemistry and recalculated-chemistry data. Average chemical composition for each detrital component was assessed both by analyses of mineral separates and recurring to a comprehensive dataset compiled from the literature, giving specific attention to Himalayan studies. The complete textural, mineralogical and chemical database is provided in Appendix A in the Supplementary material. Further information on sampling, laboratory procedures, grain-size analyses, adopted methods for mineralogical analyses including Raman spectroscopy, and comparison between optical and XRD heavy-mineral data are given in Appendix B in the Supplementary material. Assumed chemistry of detrital minerals is discussed in Appendix C in the Supplementary material.

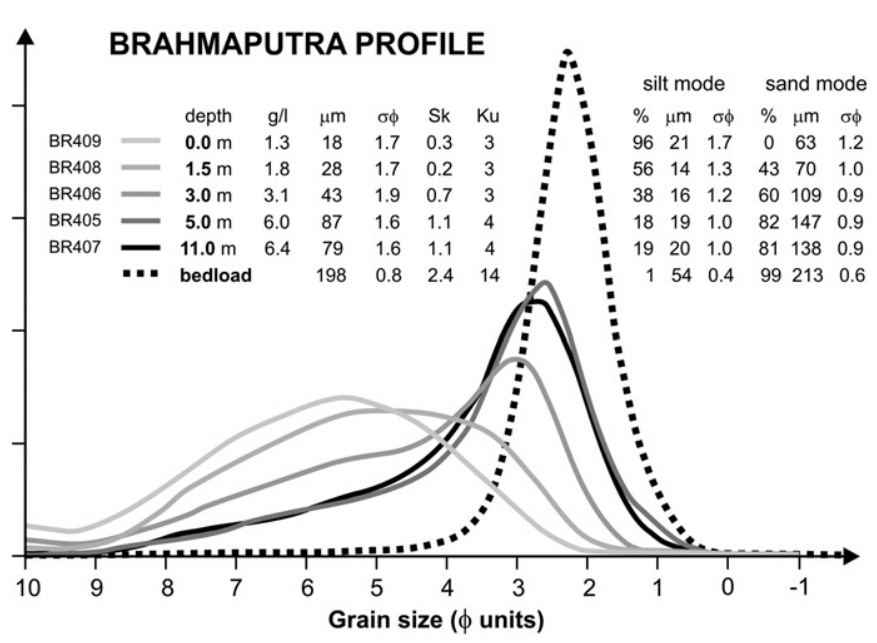

Fig. 2. Polymodal grain-size curves of sediment in transit at various depths. Sediment concentration ( $\mathrm{g} / \mathrm{l})$, mean grain size ( $\mu \mathrm{m})$, sorting ( $\sigma \phi)$, skewness and kurtosis of bulk sediment (laser analyses) are indicated, along with estimated percentages, mean size and sorting of silt and sand modes. The clay mode ranges from $3-8 \%$ at the surface to $<1 \%$ at depth. The silt mode is dominant in surface load, whereas the sand mode becomes progressively coarser and more pronounced in deep load, and eventually dominant in bedload. 
Table 1

Mineralogical composition of sediment in transit at various depths.

\begin{tabular}{|c|c|c|c|c|c|c|c|c|c|c|c|c|c|c|c|c|c|}
\hline & Depth & SRD & Quartz & $\begin{array}{l}\text { K- } \\
\text { feldspar }\end{array}$ & Albite & $\begin{array}{l}\text { Ca- } \\
\text { plagioclase }\end{array}$ & Calcite & Dolomite & Muscovite & Biotite & Chlorite & $\begin{array}{l}\text { Clay+ } \\
\text { aggregate }\end{array}$ & $\begin{array}{l}\text { Fe } \\
\text { oxides }\end{array}$ & $\begin{array}{l}\text { Heavy } \\
\text { minerals }\end{array}$ & & Opaques & Zircon \\
\hline \multicolumn{18}{|l|}{ Ganga } \\
\hline BR 716 & $0 \mathrm{~m}$ & 2.74 & 27 & 2 & 4 & 2 & 1 & 2 & 20 & 11 & 2 & 26 & 0.1 & 3 & 100.0 & 19 & 1.3 \\
\hline BR 715 & $3 \mathrm{~m}$ & 2.73 & 43 & 3 & 6 & 3 & 1 & 2 & 14 & 8 & 3 & 13 & 0.1 & 4 & 100.0 & 18 & 1.0 \\
\hline BR 714 & $8 \mathrm{~m}$ & 2.72 & 44 & 6 & 7 & 4 & 4 & 3 & 10 & 6 & 2 & 12 & 0.1 & 3 & 100.0 & 14 & 0.5 \\
\hline BR 718A & $9.8 \mathrm{~m}$ & 2.71 & 46 & 7 & 9 & 4 & 2 & 2 & 11 & 5 & 1 & 10 & 0.0 & 4 & 100.0 & 12 & 2.0 \\
\hline BR 718B & $10.3 \mathrm{~m}$ & 2.71 & 53 & 5 & 5 & 4 & 3 & 3 & 9 & 4 & 2 & 8 & 0.0 & 4 & 100.0 & 11 & 0.8 \\
\hline BR $718 \mathrm{C}$ & $10.8 \mathrm{~m}$ & 2.72 & 55 & 7 & 4 & 7 & 3 & 1 & 5 & 3 & 1 & 8 & 0.0 & 6 & 100.0 & 13 & 3.6 \\
\hline BR 717 & bedload & 2.73 & 57 & 3 & 10 & 4 & 4 & 3 & 7 & 3 & 2 & 2 & 0.0 & 6 & 100.0 & 25 & 3.7 \\
\hline \multicolumn{18}{|c|}{ Brahmaputra } \\
\hline BR 409 & $0 \mathrm{~m}$ & 2.75 & 33 & 3 & 4 & 7 & 0 & 0 & 20 & 11 & 4 & 14 & 0.2 & 4 & 100.0 & 4 & 0.0 \\
\hline BR 408 & $1.5 \mathrm{~m}$ & 2.77 & 36 & 6 & 4 & 5 & 0 & 1 & 21 & 11 & 5 & 4 & 0.1 & 6 & 100.0 & 3 & 0.4 \\
\hline BR 406 & $3 \mathrm{~m}$ & 2.76 & 41 & 7 & 5 & 10 & 0 & 1 & 13 & 12 & 2 & 3 & 0.1 & 6 & 100.0 & 5 & 0.1 \\
\hline BR 405 & $5 \mathrm{~m}$ & 2.73 & 40 & 7 & 7 & 10 & 0 & 1 & 10 & 5 & 4 & 8 & 0.0 & 7 & 100.0 & 6 & 0.5 \\
\hline BR 407 & $11 \mathrm{~m}$ & 2.76 & 37 & 8 & 6 & 15 & 0 & 0 & 12 & 12 & 3 & 2 & 0.1 & 7 & 100.0 & 7 & 2.0 \\
\hline
\end{tabular}

Bulk-sample data through selected vertical profiles for Rivers Ganga (including bedload at $\sim 11 \mathrm{~m}$ depth) and Brahmaputra were obtained by recombining Raman analyses on light fractions (10-32 and $>32 \mu \mathrm{m}$ classes), optical heavy-mineral analyses on heavy fractions ( $<10,10-32$, and $>32 \mu \mathrm{m}$ classes), and XRD analyses and optical observations on the $<10 \mu \mathrm{m}$ class. SRD=weighted average density of terrigenous grains (Garzanti and Andò, 2007). Ti oxide=anatase and brookite.

\section{Ganga-Brahmaputra suspended load}

The huge drainage basins of Rivers Ganga and Brahmaputra $\left(1,060,000 \mathrm{~km}^{2}\right.$ and $630,000 \mathrm{~km}^{2}$, respectively) include large tracts of the Himalayan belt as well as Precambrian basement of the Indian craton (Gansser, 1964). The two rivers join in central Bangladesh to form the Padma-Meghna estuary, strongly influenced by $>4 \mathrm{~m}$ tides and delivering annually to the Bay of Bengal $\sim 10^{3} \mathrm{~km}^{3}$ of water and $\geq 1.510^{6} \mathrm{t}$ of sediment, most of which during the monsoon season (Allison et al., 2003; Hay, 1998). During monsoonal floods, water discharge reaches $83,000 \mathrm{~m}^{3} / \mathrm{s}$ for the Ganga (Singh, 2007a) and $102,000 \mathrm{~m}^{3} / \mathrm{s}$ for the Brahmaputra. Estimates of suspended load are $549 \pm 5510^{6} \mathrm{t} / \mathrm{yr}$ for the Ganga and $\leq 115710^{6} \mathrm{t} / \mathrm{yr}$ for the Brahmaputra (Islam et al., 1999; RSP, 1996), which is the big-river basin with highest denudation rates on Earth (Singh, 2007b; Summerfield and Hulton, 1994). Current velocity typically decreases with depth from $\sim 3$ to $\sim 2 \mathrm{~m} / \mathrm{s}$ in River Ganga and Meghna estuary (Galy et al., 2007); depth-averaged velocity reaches $3.5 \mathrm{~m} / \mathrm{s}$ for River Brahmaputra (Best et al., 2007).

\subsection{Sediment concentration}

A regular trend in sediment concentration is invariably observed, with progressive increase from surface $(0.8 \pm 0.3 \mathrm{~g} / \mathrm{l})$, to shallow $(1.5 \pm 1.0 \mathrm{~g} / \mathrm{l}$ from 2 to $5 \mathrm{~m})$ and deep load $(2.5 \pm 1.5 \mathrm{~g} / \mathrm{l}$ from 6 to $10 \mathrm{~m}$; Fig. 2). Concentration sharply increases close to the river bed $(6.0 \pm 3.0 \mathrm{~g} / \mathrm{l})$, reaching up to $10.5 \mathrm{~g} / \mathrm{l}$. In two adjacent vertical profiles made the same day across River Ganga, sediment concentration was found to increase from $0.9 \mathrm{~g} / \mathrm{l}$ at the surface to $2.4 \mathrm{~g} / \mathrm{l}$ at $10 \mathrm{~m}$ depth in the main channel, and from $0.7 \mathrm{~g} / \mathrm{l}$ to $1.8 \mathrm{~g} / \mathrm{l}$ at the same depths closer to the bank where velocity was about half. Trends are more irregular and concentrations slightly higher at all depths in the Brahmaputra than in the Ganga, suggesting higher turbulence and vertical component of flow.

\subsection{Textures}

In River Ganga and Padma-Meghna estuary, grain size increases steadily from fine to medium silt at the surface to very coarse silt or very fine sand above the channel bed. Brahmaputra samples are commonly $0.5 \phi$ to $1 \phi$ coarser at any depth. Sorting is invariably poor. Size curves, nearly symmetrical and slightly platykurtic at the surface, become positively skewed and markedly bimodal at depth, revealing that suspended load is invariably a ternary mixture of clay with a poorly-sorted medium-silt mode and a moderately sorted very-fine to fine-sand mode. Similar polymodal size distributions, resulting from mixing of approximately lognormally-distributed subpopulations, are commonly observed in fluvial sediments (Fig. 2; Ashley, 1978; Sun et al., 2002). The Brahmaputra carries at all depths less clay mode, coarser silt mode, more sand mode, and coarser sand mode, indicating higher competence with respect to the Ganga and Padma-Meghna estuary.

Silt is here considered to include five classes (very fine 2-4 $\mu \mathrm{m}$; fine 4-8 $\mu \mathrm{m}$; medium 8-16 $\mu \mathrm{m}$; coarse 16-32 $\mu \mathrm{m}$; and very coarse 32$63 \mu \mathrm{m})$. Textural considerations through the article are based on laser data. Sieve analyses revealed significantly more fine silt and clay and less medium to coarse silt, possibly because of disaggregation of soil particles during ultrasonic treatment.

\subsection{Mineralogy}

Quartz, feldspar, and heavy minerals steadily increase with depth relative to micas (particularly muscovite) and clay-rich soil aggregates (Table 1). Composition thus changes from mica $>$ quartz $>$ feldspar in shallow load to quartz $>$ feldspar $>$ mica close to the bed. The Ganga carries more quartz and less Ca-plagioclase than the Brahmaputra (Fig. 3). Brownish soil aggregates, including organic matter, chlorite or other silicates, tiny or corroded opaque inclusions, and authigenic euhedral oxyhydroxides, are most abundant in the $<10 \mu \mathrm{m}$ fraction ( $\sim 30 \%$ in the Ganga, $\leq 20 \%$ in the Brahmaputra). Yellow-red lepidocrocite scales also occur.

Ganga suspended-load contains significant calcite and dolomite, and moderately-rich epidote-amphibole-garnet suites including clinopyroxene, tourmaline, titanite, rutile, zircon, kyanite, apatite, sillimanite, staurolite, and chloritoid; garnet increases progressively with depth relative to less dense amphibole and epidote. Brahmaputra suspended-load contains very little dolomite, no calcite, and rich amphibole-epidote suites including garnet, clinopyroxene, minor titanite, tourmaline, apatite, rutile, sillimanite, zircon, kyanite, chloritoid, staurolite, hyperstene, monazite, and $\mathrm{Cr}$-spinel (Fig. 3).

Among unstable minerals, $14 \%$ pyroxene, $49 \%$ amphibole, 53\% epidote, and $80 \%$ garnet grains appear unweathered; $32 \%$ pyroxene, $3 \%$ amphibole, and a few epidote and garnet grains are etched or exceptionally skeletal. Staurolite, titanite and even tourmaline may be etched, indicating intense weathering in monsoonal climates. Grains are more frequently weathered in coarser classes. In all size classes, garnet is more frequently corroded in Brahmaputra than in Ganga sediments; pyroxene, amphibole and epidote display similar degree of weathering in the two rivers. 


\begin{tabular}{|c|c|c|c|c|c|c|c|c|c|c|c|c|c|c|c|c|}
\hline Tourmaline & Rutile & $\begin{array}{l}\mathrm{Ti} \\
\text { oxide }\end{array}$ & Titanite & Apatite & Monazite & Amphibole & Pyroxene & Spinel & Epidote & Allanite & Chloritoid & Garnet & Staurolite & Kyanite & Sillimanite & \\
\hline 5 & 5 & 8 & 2 & 2 & 0.0 & 8 & 5 & 0.0 & 38 & 0.1 & 0.1 & 5 & 0.1 & 0.1 & 1.0 & 100.0 \\
\hline 7 & 3 & 6 & 4 & 1 & 0.0 & 17 & 6 & 0.3 & 23 & 0.0 & 0.5 & 10 & 0.2 & 1.5 & 1.0 & 100.0 \\
\hline 5 & 2 & 6 & 2 & 1 & 0.0 & 27 & 6 & 0.0 & 22 & 0.0 & 0.7 & 11 & 0.9 & 2.0 & 1.1 & 100.0 \\
\hline 7 & 4 & 2 & 3 & 2 & 0.0 & 20 & 5 & 0.0 & 25 & 1.3 & 0.0 & 13 & 0.3 & 1.7 & 2.2 & 100.0 \\
\hline 5 & 2 & 2 & 4 & 2 & 0.0 & 25 & 7 & 0.0 & 25 & 0.0 & 0.7 & 13 & 0.4 & 1.5 & 0.8 & 100.0 \\
\hline 3 & 2 & 2 & 6 & 2 & 0.0 & 21 & 5 & 0.0 & 12 & 0.0 & 0.4 & 26 & 0.4 & 2.3 & 2.1 & 100.0 \\
\hline 4 & 2 & 0 & 3 & 1 & 2.6 & 11 & 3 & 0.0 & 11 & 0.4 & 0.0 & 30 & 0.0 & 2.2 & 0.0 & 100.0 \\
\hline 2 & 1 & 3 & 2 & 0 & 0.0 & 42 & 4 & 0.7 & 34 & 0.2 & 0.4 & 4 & 0.0 & 0.3 & 0.7 & 100.0 \\
\hline 1 & 2 & 1 & 2 & 1 & 0.0 & 40 & 5 & 0.0 & 36 & 0.0 & 1.4 & 5 & 0.1 & 0.2 & 1.8 & 100.0 \\
\hline 2 & 2 & 1 & 3 & 2 & 0.0 & 47 & 5 & 0.0 & 27 & 0.0 & 0.7 & 5 & 0.0 & 0.2 & 0.6 & 100.0 \\
\hline 2 & 1 & 1 & 5 & 1 & 0.0 & 46 & 6 & 0.0 & 25 & 0.0 & 0.0 & 5 & 0.0 & 1.7 & 0.6 & 100.0 \\
\hline 2 & 1 & 1 & 4 & 2 & 0.8 & 39 & 3 & 0.1 & 32 & 0.1 & 0.8 & 3 & 0.4 & 0.0 & 1.6 & 100.0 \\
\hline
\end{tabular}

\subsection{Geochemistry}

Differences between rivers are minor and hard to detect, chemical variability of suspended-load being influenced by hydraulic, weathering, and possibly anthropic effects (Fig. 3). For a given grain size, Brahmaputra sediments are richer in $\mathrm{Na}, \mathrm{Sr}, \mathrm{Cr}, \mathrm{P}$ and possibly $\mathrm{Co}$ and $\mathrm{Ni}$, reflecting higher abundance of plagioclase, amphibole, apatite and $\mathrm{Cr}$-spinel; Ganga sediments in $\mathrm{Ca}, \mathrm{Sn}, \mathrm{As}, \mathrm{Sb}$, and $\mathrm{Bi}$, reflecting more abundant carbonates and soil particles.

Steady trends with depth reflect regular textural and mineralogical changes through the water column. Because of progressive enrich- ment in slow-settling phyllosilicates toward the surface, elements mostly hosted in micas or associated with clay, oxyhydroxides and organic matter, including heavy metals and constitutive water, are concentrated in surface load (Al, Fe, Mg, K, Ti, P, Mn, Rb, Cs, Be, Ba, V, $\mathrm{Cr}, \mathrm{Mo}, \mathrm{W}, \mathrm{Co}, \mathrm{Ni}, \mathrm{Cu}, \mathrm{Zn}, \mathrm{Ga}, \mathrm{Ge}, \mathrm{Pb}, \mathrm{As}, \mathrm{Sb}$, and $\mathrm{Bi}$; LOI). Instead, because of progressive enrichment in fast-settling coarser, denser, and more spherical grains toward the bed, elements mostly hosted in tectosilicates ( $\mathrm{Si}, \mathrm{Na}, \mathrm{Ca}$, and $\mathrm{Sr}$ ) or ultradense minerals ( $\mathrm{Zr}$ and $\mathrm{Hf}$ ) are concentrated in deep load (Fig. 4). Other elements hosted in ultradense minerals but also associated with fine particles (Y, REE, Th, U, Ti, Nb, Ta, Cr, W, Mn, Fe, Cd, Ge, Sn, and P) reach maximum

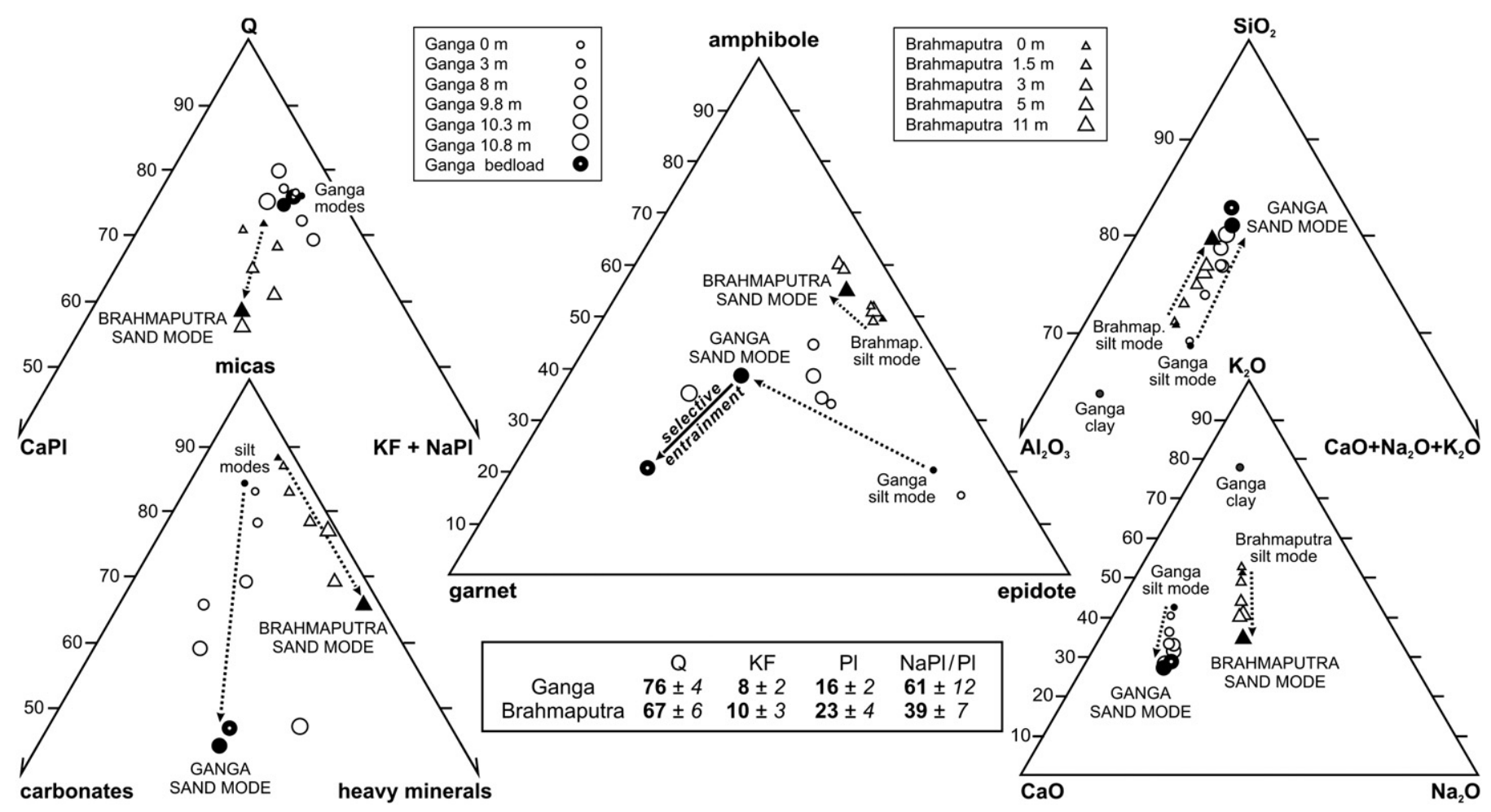

Fig. 3. Intersample compositional variability. Mineralogical data better document provenance-related differences between Ganga load, containing more quartz (Q), carbonates and garnet, and Brahmaputra load, containing more Ca-plagioclase ( $\mathrm{Pl}$ ) and amphibole. Chemical data largely reflect suspension-sorting effects (e.g., $\mathrm{Al}_{2} \mathrm{O}_{3} / \mathrm{SiO}_{2}$ and $\mathrm{K}_{2} \mathrm{O}$ steadily decrease with depth). Plagioclase-rich Brahmaputra sediments are richer in Na, but poorer in Ca because of extensive carbonate dissolution. Arrows outline steady compositional trends from shallow to deep load. $\mathrm{KF}=\mathrm{K}$-feldspar; $\mathrm{Na}-\mathrm{Pl}=$ albite. 
abundance in deepest suspended load particularly above heavymineral-enriched bedload, but are also enriched in surface load.

Chondrite-normalized REE patterns invariably display classical LREE enrichment, negative Eu anomaly, and flat HREE distribution (McLennan, 1989). The marked decrease from La to $\mathrm{Sm}\left(\mathrm{La}_{N} / \mathrm{Sm}_{N}\right.$ $3.7 \pm 0.1)$ reflects dominant allanite and monazite contributions. The lesser decrease from $\mathrm{Gd}$ to $\mathrm{Ho}\left(\mathrm{Gd}_{N} / \mathrm{Ho}_{N} 1.6 \pm 0.1\right)$ reflects contributions also from titanite and apatite, having less steep REE patterns (Bea, 1996). The flat HREE pattern $\left(\mathrm{Ho}_{\mathrm{N}} / \mathrm{Yb}_{\mathrm{N}} 1.0 \pm 0.0\right)$ reflects contribution from xenotime, titanite, garnet, and subordinately zircon that has steep rising HREE pattern (Fig. 5; Rubatto, 2002).

Because of progressive concentration of fast-settling ultradense minerals at depth, the Eu anomaly becomes slightly but steadily more negative from surface $\left(\mathrm{Eu} / \mathrm{Eu}^{*} 0.64 \pm 0.02\right.$, close to $\mathrm{Eu} / \mathrm{Eu}^{*}{ }_{\text {Ucc,PAAS }}=$ $0.65)$ to deep load $\left(\mathrm{Eu} / \mathrm{Eu}^{*} 0.61 \pm 0.03\right)$. Deepest suspended load above heavy-mineral-enriched bedload displays marked enrichment in REE, steeper LREE patterns $\left(\mathrm{La}_{N} / \mathrm{Sm}_{\mathrm{N}} 4.1 \pm 0.2\right)$, and $\mathrm{Eu} / \mathrm{Eu}^{*}$ as low as 0.35 (Fig. 6). This indicates concentration of monazite and allanite, both commonly characterized by strongly negative Eu anomalies (Bea, 1996). Hydraulic-sorting effects should thus be taken into full account while making provenance inferences based on the Eu anomaly, widely considered as a conservative provenance proxy (Condie, 1993; Cullers, 1995; McLennan, 1989; Mongelli et al., 2006).

Significant weathering effects are documented by systematic depletion in mobile $\mathrm{Na}, \mathrm{Ca}$, and $\mathrm{Sr}$ relative to UCC in both suspended load and bedload. Elements such as $\mathrm{Al}, \mathrm{Fe}, \mathrm{V}, \mathrm{Co}, \mathrm{Ni}, \mathrm{Cu}, \mathrm{Zn}, \mathrm{Ga}, \mathrm{Sn}, \mathrm{Pb}$, $\mathrm{As}$, and $\mathrm{Sb}$ are depleted in bedload and progressively enriched in shallower suspended load. This suggests removal from primary minerals (e.g., Al and Ga from feldspar, other elements from oxides or sulfides; Galy and France-Lanord, 1999), and involvement in formation of clays and oxyhydroxides (Datta and Subramanian, 1998; Shamsudduha et al., 2008). Depletion in mobile Mo is particularly strong in deep load. Human activities may have fostered enrichment in $\mathrm{Cr}, \mathrm{Ni}, \mathrm{Cu}, \mathrm{Zn}, \mathrm{Cd}, \mathrm{Pb}, \mathrm{P}, \mathrm{As}, \mathrm{Sb}$, and $\mathrm{Bi}$ in particulate matter (Viers et al., 2009). Heavy-metal pollution, most significant in urban and industrial areas (e.g., Singh et al., 2002), is strongly diluted during huge monsoonal flux (Datta and Subramanian, 1997; Ramesh et al., 2000).

Enrichment in Y, REE, Th, and U relative to UCC in both bedload and suspended load, besides provenance effects, reflects their concentration in weathering-resistant ultradense minerals as well as in phyllosilicates and particulate matter. The observed enrichment sequence Th>MREE > LREE, Y, HREE, U, with characteristic MREEbulge behaviour (Fig. 4; Haley et al., 2004; MREE/MREE* $1.15 \pm 0.01$ in surface load) may reflect scavenging of Th and MREE onto Feoxyhydroxides and clays (Degueldre and Kline, 2007; Quinn et al., 2006).

Chemical weathering indices are similar in Ganga and Brahmaputra sediments, and intermediate between UCC and PAAS, suggesting significant weathering in monsoonal climates. Regular decrease with depth (Fig. 6; CIA $69 \pm 5$, WIP $51 \pm 6$ at surface, CIA $61 \pm 3$, WIP $42 \pm 5$ at $\geq 8 \mathrm{~m}$ depth) is largely an hydraulic-sorting effect, being a consequence of decreasing $\mathrm{Al}$ (mainly associated with phyllosilicates) and increasing $\mathrm{Na}$ and $\mathrm{Ca}$ (mainly associated with plagioclase), only partly counterbalanced by a decrease in $\mathrm{K}$ and Mg. Lower WIP in deep load reflects decrease of slow-settling K-rich phyllosilicates rather than stronger weathering.

\section{Modeling size distribution}

Texture, mineralogy and chemistry of Ganga-Brahmaputra sediments indicate that they are a mixture of chiefly Himalayan-derived sand, of largely Himalayan-derived silt-dominated mud with major contributions from floodplain soils, and of clay-dominated mud largely derived from the floodplain and craton (France-Lanord et al., 1993; Galy et al., 2007). Clay, silt and sand are thus the diverse products of physical and chemical processes operating differently in different parts of the basin, and not merely conventional classes separated by arbitrarily chosen size limits.

\subsection{Analysis of polymodal suspended load}

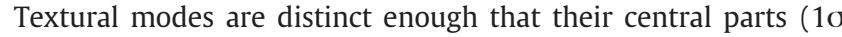
each side of the mean) show little overlap. Clay and silt modes are separated by a distinct minimum observed at $\sim 2 \mu \mathrm{m}$ in all grain-size distributions (Fig. 2). Such a gap resulted apparent in the laboratory, where the $<10 \mu \mathrm{m}$ class readily divided by centrifuging into relatively fast-settling fine silt and a cloud of clay remaining in suspension for long. Overlap between silt and sand modes is more significant but decreases in deeper suspended-load, because the former is nearly invariant, whereas the latter gradually becomes progressively coarser and slightly better sorted (Fig. 2). Because of limited overlap, the fine half of the silt-mode (very-fine to medium silt) and the coarse half of the sand-mode are nearly pure. With the assumption that each mode

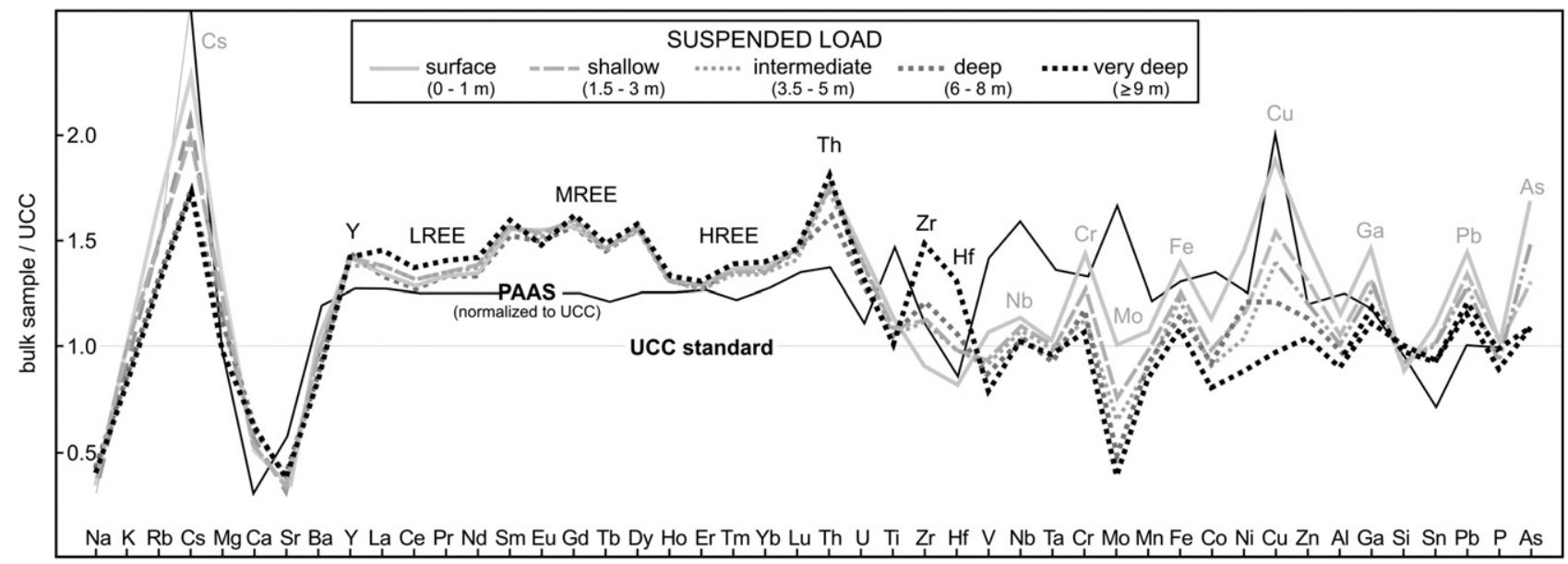

Fig. 4. Chemical composition of suspended sediment at various depths (elements in UCC-normalized multielement diagram arranged following the periodic table group by group). Systematic depletion in Na, Ca, and Sr, and enrichment in Th and YREE (especially MREE) with trends close to PAAS, are largely a weathering effect. Concentration of Zr and Hf in deep load and of Cs, V, Cr, Mo, Mn, Fe, Co, Ni, Cu, Zn, Al, Ga, Pb, and As in surface load is a suspension-sorting effect. Mo is most strongly depleted in deep load. Data are averages of 8 to 15 Ganga, Brahmaputra and Padma-Meghna samples for each depth interval. 

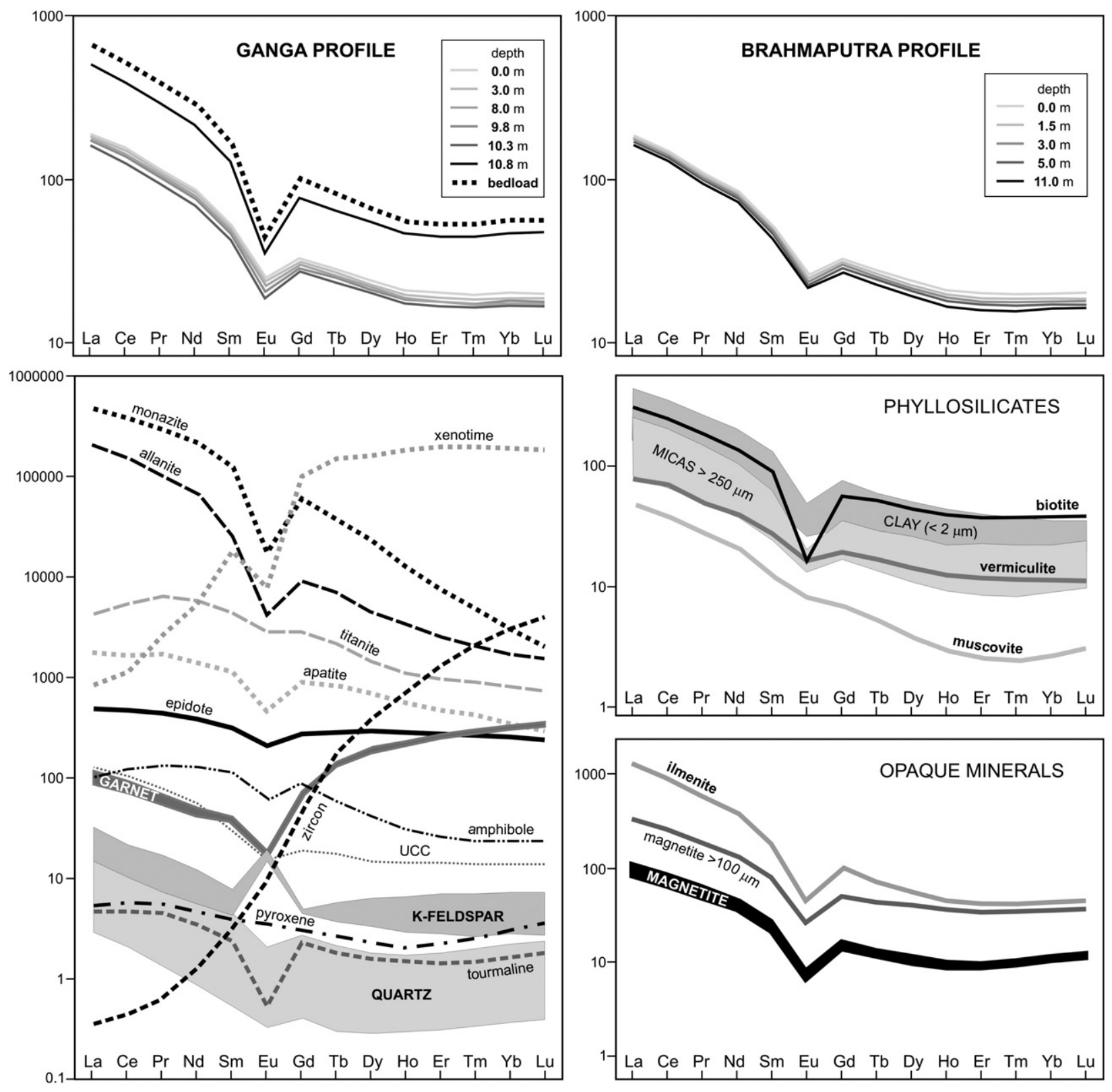

Fig. 5. Chondrite-normalized REE patterns of bulk sediments (upper panels) and diverse detrital minerals (lower panels) in Rivers Ganga and Brahmaputra. In the Ganga profile, note the sharp increase in REE and negative Eu anomaly in deepest load above heavy-mineral enriched bedload. REE concentrations for each mineral were determined by chemical analyses of single (continuous lines) to multiple separates (shaded fields; complete dataset provided in Garzanti et al. (2010)), or assumed from compiled literature information (dashed and dotted lines; criteria illustrated in Appendix C). Higher REE in the magnetite separate $>100 \mu \mathrm{m}$ reflect occurrence of common ilmenite-bearing composite grains, as revealed by higher Ti, Nb, and Ta. Micas $>250 \mu \mathrm{m}$ represent the coarsest tail of three Ganga, Brahmaputra and Padma bar sands; clay $<2 \mu \mathrm{m}$ the finest tail of three Ganga suspended load and bank deposits.

is lognormally distributed and symmetrical (Ashley, 1978; Clark, 1976; Tanner, 1964), silt and sand modes in each sample were thus calculated as the double of the silt-mode fine half and sand-mode coarse half, respectively. In such simple empirical way, size distribution of all samples could be nearly perfectly modeled as ternary mixtures of lognormal subpopulations.

The mineralogy of silt and sand modes was assessed by best-fit calculations on integrated bulk-sample grain-size and multiplewindow mineralogical datasets. Because multiple-window chemical data were limited to one Ganga sample, chemistry of silt and sand modes had to be calculated indirectly from the bulk-sample dataset. As a simpler alternative way, considering that surface load chiefly consists of silt mode and deepest load chiefly of sand mode, mineralogy and chemistry of silt and sand modes can be estimated by linear regression of mineralogical and chemical data for each vertical profile in each river (methods and results illustrated in detail in Appendix D in the Supplementary material).

\subsection{The clay mode}

Laser analyses indicate that clay decreases progressively from $5 \pm$ $1 \%$ at the surface to $1 \pm 1 \%$ at $>7 \mathrm{~m}$ depth, becoming negligible in bedload; sieve analyses indicate about double values. Clay is richer than both silt and sand modes in $\mathrm{Al}, \mathrm{Fe}, \mathrm{Mg}, \mathrm{P}, \mathrm{Mn}, \mathrm{Cs}, \mathrm{V}, \mathrm{Cr}, \mathrm{Mo}, \mathrm{Co}, \mathrm{Ni}$, $\mathrm{Cu}, \mathrm{Zn}, \mathrm{Cd}, \mathrm{Ga}, \mathrm{Pb}, \mathrm{As}, \mathrm{Sb}$, and $\mathrm{Bi}$, and poorer in $\mathrm{Si}, \mathrm{Na}, \mathrm{Ca}$, and $\mathrm{Sr}$ (Fig. 7). Very low in the $<2 \mu \mathrm{m}$ class (CIA $84 \pm 2$, WIP $39 \pm 3$ ), Ca and Na are 


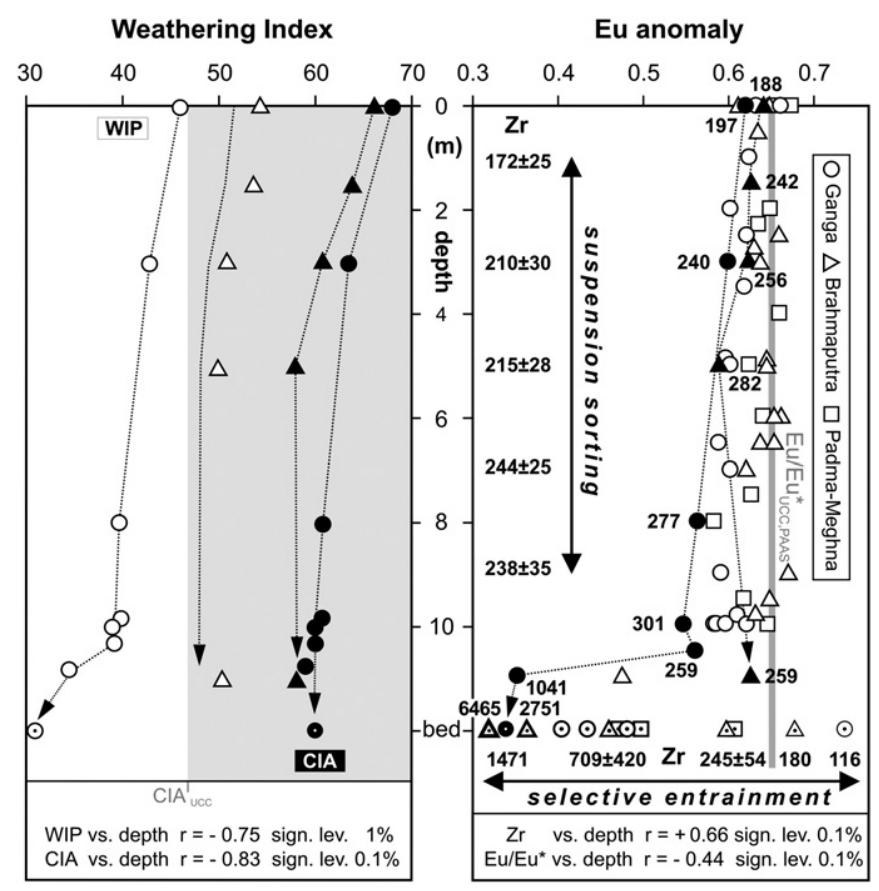

Fig. 6. Hydraulic control on intersample chemical variability. Left panel) Because of suspension sorting, weathering indices decrease with depth through Ganga and Brahmaputra profiles. Slightly higher CIA (black symbols) and lower WIP (open symbols) suggest somewhat stronger weathering in Ganga plains. Shaded grey is range between CIA values for UCC and PAAS. Right panel) Negative Eu anomaly and Zr concentration increase steadily with depth, reflecting enrichment of fast-settling ultradense minerals (black symbols for Ganga BR716/717 and Brahmaputra BR409/ BR407 vertical profiles). In the Ganga profile, the increase becomes much faster close to the bed, where ultradense minerals are markedly enriched by selective entrainment. Heavy-mineral-depleted bedload, instead, displays less negative Eu anomaly and lower $\mathrm{Zr}$ concentration than UCC.

virtually absent in the $<0.1 \mu \mathrm{m}$ class (CIA 94, WIP 22). Strong decrease in elements associated with the detrital fraction ( $\mathrm{Na}, \mathrm{K}, \mathrm{Ca}, \mathrm{Sr}, \mathrm{LREE}$, $\mathrm{Zr}, \mathrm{Hf}, \mathrm{Nb}$, and $\mathrm{Ta}$ ) and lanthanide fractionation indicate that the $<0.1 \mu \mathrm{m}$ class largely consists of authigenic material including poorly crystallized Fe-oxyhydroxides. The Ce anomaly, invariably negligible in bulk samples, is weakly positive in the $<0.1 \mu \mathrm{m}$ class $\left(\mathrm{Ce} / \mathrm{Ce}^{*} 1.06\right)$, which might suggest adsorption or co-precipitation of $\mathrm{CeO}_{2}$ on clay or Fe-oxyhydroxide coatings. This would be consistent with Fe increase, depletion in $\mathrm{U}$ (dissolved as $\mathrm{UO}^{2+}$ ions in oxic conditions fostering $\mathrm{Ce}$ scavenging), and prominent MREE bulge (MREE/MREE* $1.19 \pm 0.04$ in the $<2 \mu \mathrm{m}$ class, MREE/MREE ${ }^{*} 1.34$ in the $<0.1 \mu \mathrm{m}$ class). Attenuation of the negative Eu anomaly (Eu/Eu* 0.69 in the $<0.1 \mu \mathrm{m}$ class) might suggest selective Eu adsorption on smectite (Takahashi et al., 2004). Kaolinite and smectite are in fact abundant in Bangladesh, whereas illite and chlorite are dominant in Himalayan reaches (Heroy et al., 2003; Islam and Lotse, 1986; Sarin et al., 1989; Singh et al., 2005).

\subsection{The silt mode}

Laser analyses of surface load display a broad bell-shaped curve dominated by medium to coarse silt, becoming a progressively less elevated plateau in deeper load (Fig. 2). Such silt mode decreases steadily from $93 \pm 3 \%$ at surface to $39 \pm 14 \%$ at $>7 \mathrm{~m}$ depth. Mean grain size is remarkably constant, ranging from $6.4 \pm 0.2 \phi$ (PadmaMeghna surface load) to $6.0 \pm 0.2 \phi$ (Brahmaputra deep load); sorting is invariably poor $(1.4 \pm 0.2 \sigma \phi)$. The silt mode becomes minor $(2 \pm$ $1 \%)$, markedly coarser $(4.2 \pm 0.7 \phi)$, and better sorted $(0.4 \pm 0.2 \sigma \phi)$ in bedload. Mineralogy is mica $\approx$ quartz $>$ feldspar, with calcite, dolomite and moderately-poor epidote-hornblende-garnet suites

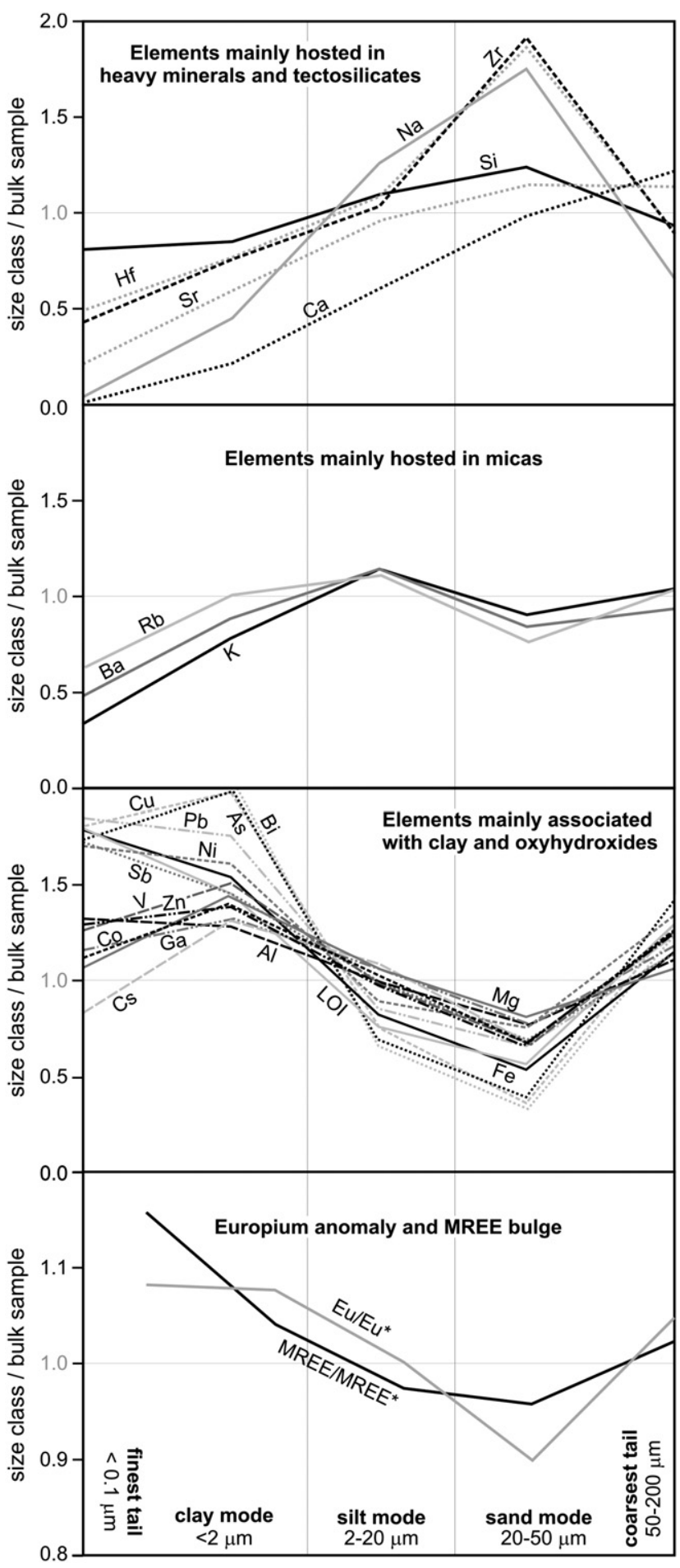

Fig. 7. Intrasample chemical variability of Ganga surface load (sample BR522; data normalized to bulk-sample composition). Elements mainly hosted in tectosilicates ( $\mathrm{Si}$ and $\mathrm{Na}$ ) and heavy minerals ( $\mathrm{Zr}$ and $\mathrm{Hf}$ ) are concentrated in the sand mode, where the negative Eu anomaly reaches maximum and the MREE-bulge minimum. Elements mainly hosted in micas ( $\mathrm{K}, \mathrm{Rb}$, and $\mathrm{Ba}$ ) are concentrated in the silt mode. Elements associated with clay, Fe-oxyhydroxides and organic matter are concentrated in the clay mode; all elements associated with phyllosilicates increase again in the mica-rich coarse tail of the sand mode.

for Ganga silt, and with trace dolomite and moderately-rich hornblende-epidote suites for Brahmaputra silt. Muscovite prevails over biotite and chlorite. Soil aggregates with Fe-oxyhydroxides and organic matter are common. Chemical composition is largely intermediate between clay and sand modes, but strongly enriched 
with respect to both in $\mathrm{K}, \mathrm{Rb}$, and $\mathrm{Ba}$, reflecting concentration of micas (particularly illite/muscovite; Fig. 7).

\subsection{The sand mode}

The sand mode, revealed by a shoulder in the coarse tail of size distributions, is negligible in surface load $(\leq 1 \%)$, becomes progressively more prominent and coarser in deeper load, and finally rises to a sharp narrow peak in bedload ( $98 \pm 1 \%$; Fig. 2). Mean grain size and sorting are $3.8 \pm 0.7 \phi$ and $0.9 \pm 0.2 \sigma \phi$ for shallow load $(\leq 5 \mathrm{~m})$, $3.2 \pm 0.4 \phi$ and $0.8 \pm 0.1 \sigma \phi$ for deeper load, $2.2 \pm 0.3 \phi$ and $0.5 \pm 0.1$ $\sigma \phi$ for bedload. Mineralogy is quartz $>$ feldspar $>$ mica, with biotite prevailing over muscovite. Ganga sand contains calcite, dolomite, and moderately-rich to rich suites including subequal hornblende, epidote, and garnet; Brahmaputra sand contains trace dolomite and rich hornblende-epidote suites. The sand mode is richer than both silt and clay in $\mathrm{Si}, \mathrm{Na}, \mathrm{Ca}, \mathrm{Zr}$, and $\mathrm{Hf}$ ( $\mathrm{Sr}$ in Brahmaputra and PadmaMeghna), reflecting hydraulic concentration of tectosilicates and heavy minerals relative to phyllosilicates (Fig. 7).

\subsection{The origin of clay, silt, and sand}

Clay, silt and sand modes are compositionally distinct, reflecting hydraulic-sorting effects superposed on detritus shed from distinct and differently weathered sources (e.g., soil, landslide, and till) and lithologies (sedimentary, metamorphic, plutonic, minor volcanic and ultramafic rocks) in diverse catchment areas (e.g., mountains, floodplain, craton). The origin of clay, silt, and sand can be investigated by comparing the chemical composition of the $<2 \mu \mathrm{m}$ class (clay mode), of silt-dominated surface load (proxy for silt mode), and of sand-dominated bedload (proxy for sand mode) for River Ganga in Bangladesh versus its upstream Nepal tributaries (data after Galy et al. (2007)).

Alkali and alkaline-earth metals are invariably higher in sand than in silt, and in silt than in clay, but all three modes in Bangladesh are strongly depleted in Ca, largely reflecting calcite dissolution (carried to completion in the Brahmaputra floodplain; Garzanti et al., 2004; Singh et al., 2005). Ganga clay is strongly depleted in K, reflecting modification of clay minerals in the floodplain. Instead, $\mathrm{K}$ does not change in either suspended-load silt or bedload sand, suggesting minor leaching of other K-bearing detrital silicates. Weathering indices for Ganga clay (CIA $84 \pm 2$, WIP $39 \pm 3$ ) are much closer to clay in floodplain soils (CIA $87 \pm 1$, WIP $37 \pm 2$ ) than to clay in Nepal tributaries (CIA $74 \pm 9$, WIP $61 \pm 8$ ), documenting major contribution from the intensely cultivated floodplain or craton (Galy et al., 2007).

As the clay mode is the ultimate result of chemical weathering, the sand mode at the other extreme is largely the product of physical erosion and mechanical grinding during transport in mountain streams (Attal and Lavè, 2006), as shown by weathering indices close to UCC for bedload from Nepal (CIA $56 \pm 6$ ) to Bangladesh (CIA $55 \pm 4$ ). The silt mode, characterized by weathering indices close to PAAS and intermediate between clay and sand, is the result of both physical and chemical processes, and may largely derive from erosion of soil profiles in both mountain catchments and alluvial plains. Exchange during floods between sequestered fresh mud and pedogenized mud eroded from banks, islands, and floodplain is suggested by common occurrence of soil aggregates and intermediate weathering indices between surface load in Nepal tributaries and floodplain soils.

\section{Modeling intrasample variability}

In traction-current deposits, grains are in settling equivalence (i.e., coarser low-density or platy grains are associated with smaller denser or more spherical grains having the same settling velocity; Rubey, 1933). If we split any sorted sediment sample in its size classes, these will display marked and predictable differences in mineralogical composition, with progressive enrichment in denser minerals in finer classes and of lighter and platier minerals in coarser classes (Rittenhouse, 1943; Schuiling et al., 1985). Suspended load in transit, however, consists of a ternary mixture of clay, silt and sand modes, and the settling-equivalence principle applies to each. Which implies that, for instance, the very-coarse-silt class of any sample will include the heavy-mineral-rich fine tail of the sand mode, together with the coarse tail of the silt mode enriched in platy phyllosilicates. Although settling velocities of silt-sized minerals are easily calculated with Stokes' law and their size shifts do not depend on settling velocity and grain size (Garzanti et al., 2008), occurrence of mixed modes makes settling-equivalence analysis of suspended load more complex than for bedload.

\subsection{Settling velocity of silt and sand grains}

The settling velocity $v$ for laminar flow past spherical silt-sized grains is given by Stokes' law:

$v=g \cdot \Delta_{m} \cdot D_{m}^{2} / 18 \eta$
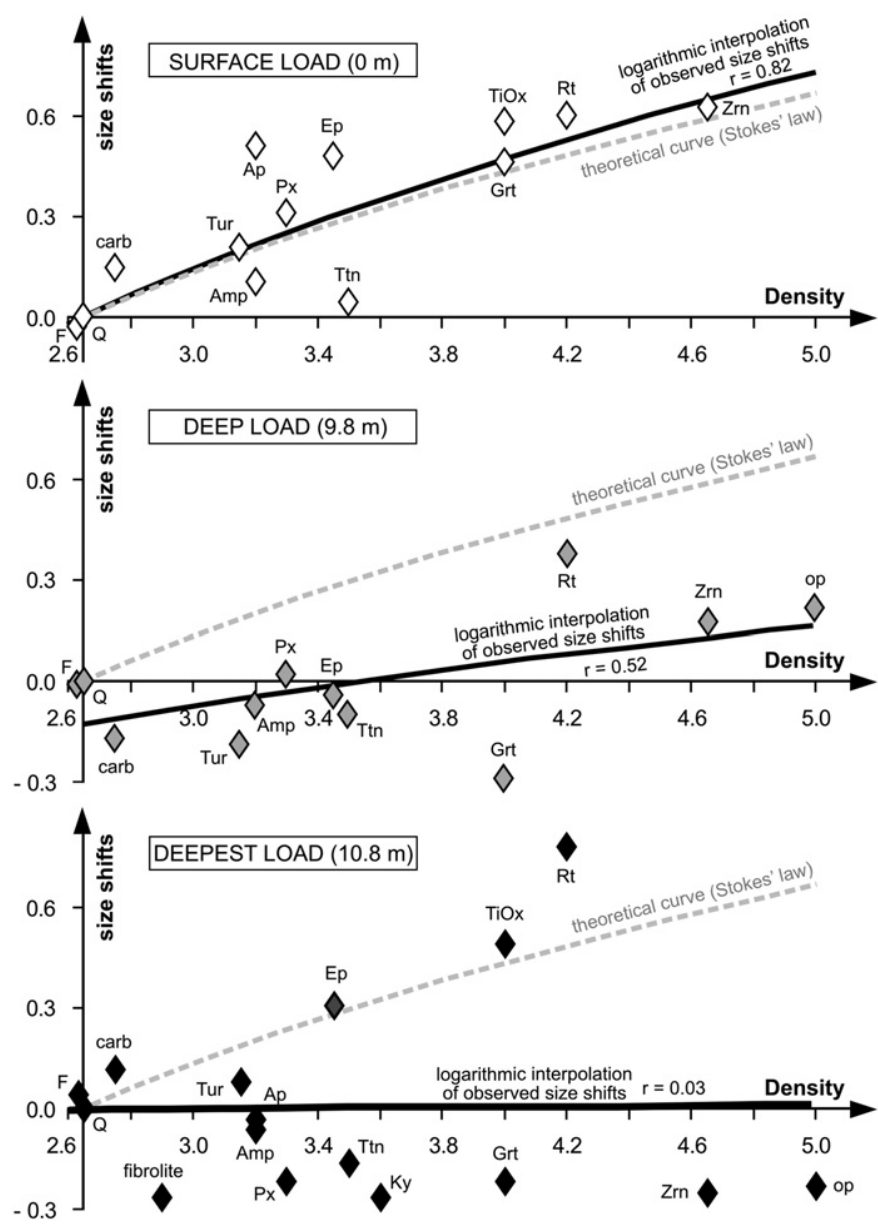

Fig. 8. Settling-equivalence analysis of Ganga suspended load. Size-density correlations, relatively good in surface load chiefly consisting of silt mode, decrease and eventually become null at depth, where the heavy-mineral-rich sand mode becomes progressively more abundant and coarser. Size shifts tend to be higher for minerals relatively enriched in the silt mode (epidote, Ti oxide) and lower - and eventually negative in deep load - for minerals concentrated in the sand mode (garnet, zircon, kyanite, and titanite). Platy phyllosilicates were neglected in calculating the correlation coefficient. Size shifts are imprecisely determined because few size classes were analysed. Mineral abbreviations: $A m p=$ amphibole; $A p=$ apatite; carb $=$ carbonates; $\mathrm{Ep}=$ epidote; $\mathrm{F}=$ feldspar; $\mathrm{Grt}=$ garnet; $\mathrm{Ky}=$ kyanite; op=opaques; $\mathrm{Px}=$ pyroxene; $\mathrm{Q}=$ quartz; Rt = rutile; TiOx = anatase, brookite; Ttn = titanite; Tur = tourmaline; $\mathrm{Zrn}=$ zircon. 
where $\mathrm{g}=$ gravity; $\mathrm{D}_{\mathrm{m}}=$ diameter of mineral $\mathrm{m} ; \Delta_{\mathrm{m}}=$ submerged density (mineral density $\delta_{\mathrm{m}}$-fluid density $\delta_{\mathrm{f}}$ ); $\eta=$ fluid viscosity (in freshwater $\delta_{\mathrm{f}}=1 \mathrm{~g} / \mathrm{cm}^{3}$ and $\eta=0.01 \mathrm{~g} / \mathrm{cm} \mathrm{s}$ ). In order to take into account the slower settling velocity of non-spherical grains (Baba and Komar, 1981; Briggs et al., 1962), Stokes' equation was modified by Komar and Reimers (1978):

$v=g \cdot \Delta_{m} \cdot D_{N}^{2} /(18 \eta \cdot f(C S F))$.

The nominal diameter $D_{N}$ is $\left(D_{s} \cdot D_{i} \cdot D_{1}\right)^{1 / 3}$ for an ellipsoidal particle with short, intermediate, and long axes $D_{s}, D_{i}$ and $D_{1}$. The Corey Shape Factor CSF is $D_{s} /\left(D_{i} \cdot D_{1}\right)^{1 / 2}$. The functional relationship $f$ (CSF) was empirically assessed as $=0.946 \mathrm{CSF}^{-0.378}$ if $0.4 \leq \mathrm{CSF} \leq 0.8$, and as $=2.18-2.09$ CSF if $\mathrm{CSF}<0.4$. CSF is here assumed to be 0.7 for quartz and most natural grains, and 0.1 for platy phyllosilicates (Dietrich, 1982; Komar et al., 1984). For silt-sized grains with CSF 0.7 and 0.1 , settling velocity calculated by Eq. (2) is $92 \%$ and $51 \%$ that predicted by Stokes' law, respectively.

For sand-sized grains, Stokes' equation and its empirical modifications give much too high values, and settling velocity has to be calculated by empirically calibrated formulas, such as that proposed by Cheng (1997) and tested for natural grains with CSF 0.7, densities in the $2.0-4.3 \mathrm{~g} / \mathrm{cm}^{3}$ range, and Reynolds numbers $1<\mathrm{R}<1000$ (corresponding to detrital quartz $\sim 0.1$ to $\sim 4 \mathrm{~mm}$ in size):

$v=\left(\left(25+1.2\left(\left(g \cdot \Delta_{m} \cdot D_{m}^{3} / \eta^{2}\right)^{2 / 3}\right)\right)^{1 / 2}-5\right)^{3 / 2} \cdot \eta / D_{m}$.

For medium-silt-sized grains with CSF 0.7 and 0.1 , settling velocities predicted by Eq. (2) are $124 \%$ and $68 \%$ (58\% for Eq. (6) in Komar et al. (1984); 69\% for Eq. (42) in Le Roux (2005)) those predicted by Eq. (3), respectively.

The size shift for mineral $m$ (difference in nominal diameter relative to quartz $q$ ) predicted by Stokes' law is:

$S S_{m}=\log _{2}\left(\Delta_{m} / \Delta_{q}\right) / 2$.

\subsection{Intrasample compositional variability}

Within each sample, different size classes have systematically different composition largely because they include different proportions of clay, silt, and sand modes. The $<10 \mu \mathrm{m}$ class consists of silt mode with $12 \pm 3 \%$ clay, the $10-32 \mu \mathrm{m}$ class of silt mode with $7 \pm 8 \%$ sand mode, and the $>32 \mu \mathrm{m}$ class of silt mode with $2 \pm 6 \%$ sand mode in surface load and of sand mode with $11 \pm 5 \%$ silt mode in deep load. Consequently, composition changes from quartz $\approx$ soil aggregates $\approx$ mica $>$ feldspar (Ganga) or mica $>$ quartz $>$ soil aggregates $\approx$ feldspar (Brahmaputra) in the $<10 \mu \mathrm{m}$ class, to quartz $>$ feldspar $>$ mica in the $>32 \mu \mathrm{m}$ class.

In apparent contrast with the settling-equivalence principle, heavy-mineral concentration in several samples reaches maximum in the very-coarse-silt class, shows a minimum in the medium-coarse silt class (where weighted-average density of heavy minerals also generally reaches minimum), to increase again in the fine-silt class. The major coarser and the lesser finer heavy-mineral peaks correspond to the fine tails of the sand and silt modes, respectively rich and moderately-rich in heavy minerals. Because silt and sand modes have slightly different compositions, most evident in Ganga samples, the coarser peak is generally garnet-rich, and the finer peak epidote-rich.

A similarly bimodal distribution is displayed by chemical composition of surface load. Both the $2-20 \mu \mathrm{m}$ class (containing the bulk of the phyllosilicate-rich silt mode) and the 50-200 $\mu \mathrm{m}$ class (containing the mica-enriched coarse tail of the sand mode) show greater abundance of elements associated with phyllosilicates, organic matter and Fe-oxyhydroxides (Al, Fe, Mg, K, Ti, Rb, Cs, Be, Ba, V, Nb, Cr, W, Co, $\mathrm{Ni}, \mathrm{Cu}, \mathrm{Zn}, \mathrm{Ga}, \mathrm{Ge}, \mathrm{Sn}, \mathrm{Pb}, \mathrm{As}, \mathrm{Sb}$, and Bi). Instead, elements contained in tectosilicates or heavy minerals ( $\mathrm{Si}, \mathrm{Na}, \mathrm{Sr}, \mathrm{Zr}$, and $\mathrm{Hf}$ ) reach maximum in the $20-50 \mu \mathrm{m}$ class (including the finer half of the sand mode), where $\mathrm{Eu} / \mathrm{Eu}^{*}$ (0.58) and MREE/MREE* (1.11) reach minimum (Fig. 7).

\subsection{Settling-equivalence analysis of polymodal suspended load}

In order to quantify compositional variability, and to check the overall consistency of size distribution and mineralogy estimated for each mode in each river branch, mineralogy and chemistry of any size class can be predicted for any ternary mixture of clay, silt, and sand modes with a settling-equivalence model based on a standard spreadsheet (Garzanti et al., 2009). Considering that size shifts could not be measured precisely, given the limited number of sieved classes and Raman-counted grains on each slide (particularly for rare components), the observed intrasample mineralogical variability is reproduced with satisfactory accuracy by the model.

Even if platy phyllosilicates with anomalous hydraulic behaviour are neglected, size-density correlations and size-shift coefficients rapidly decrease and eventually become null when different modes are mixed in progressively greater proportions. Only in surface load, chiefly consisting of silt mode, are size-density correlations relatively good $(r=0.8 \pm 0.1)$, and size-shift coefficients not much lower $(-36 \pm 29 \%)$ than predicted by Eq. (4). In deep load, the sand mode becomes progressively coarser and more abundant, while the silt mode remains nearly invariant. Heavy-mineral species, strongly concentrated in the sand mode, thus become coarser not only than micas, dominating the silt mode, but even than quartz (negative size shifts; Fig. 8). Better agreement between observed and predicted size shifts is obtained by assuming better sorting of fast-settling heavy minerals relative to quartz and feldspar, and poorer sorting of slowsettling phyllosilicates, a consequence of their widely varying density (from $<2.6$ for vermiculite to $>2.9$ for biotite) and shape (CSF as low as 0.007-0.05; Doyle et al., 1983).

\section{Modeling intersample variability}

According to the settling-equivalence principle, at each depth finergrained dense minerals are found associated with coarser low-density minerals and even coarser platy micas. If all mineral species were available in equal relative quantities for all size classes, progressively coarser grains of each species would be found at increasing water depths, but their relative concentration would not vary, and composition of suspended load would be constant with depth.

In reality this is never the case, because fluvial sediments are mixtures of clay, silt, and sand modes produced by diverse physical and chemical processes and characterized by different settling velocity and composition. Regular textural, mineralogical, and chemical trends through the water column are thus observed in Ganga-Brahmaputra suspended load, chiefly reflecting segregation of faster-settling heavy minerals and tectosilicates in the sand mode, and of silt-sized phyllosilicate flakes and clay in finer modes.

\subsection{Calibrating abundances of rare minerals}

The simplest way to model intersample variability is to combine relative abundances of clay, silt, and sand modes estimated for each sample with the estimated mineralogy of Ganga and Brahmaputra silt and sand modes. Relative abundance of each detrital component in each sample is thus determined as a weighted average; volume percentages are next converted into weight percentages, and bulksample chemistry recalculated. Comparison between observed and predicted mineralogy and chemistry for each sample and compositional trends with water depth allows us to verify and refine all 
underlying assumptions, including mineralogy of silt and sand modes and chemistry of diverse detrital minerals, until a satisfactory general fit is obtained.

The process is not straightforward, but particularly useful to calibrate abundances of dense and ultradense minerals such as zircon, monazite, xenotime, allanite, titanite, and apatite, which are too rare to be determined precisely with optical analyses but contribute much of key chemical elements (P, Y, REE, Th, U, Zr, and Hf; Bea, 1996; Spear and Pyle, 2002). Percentages of these minerals in each river may thus be estimated reliably, which is crucial for provenance analyses based on age populations of detrital zircon or apatite (Dickinson, 2008; Malusà et al., 2009; Moecher and Samson, 2006), as well as for settlingequivalence and selective-entrainment studies (Garzanti et al., 2009).

\subsection{The mineralogical-chemical budget}

In theory, if mineralogical and chemical composition is perfectly determined for each sample, and chemical composition correctly assumed for all detrital components, then we can calculate exactly how much of each chemical element is contributed by each detrital mineral to each sample. In practice, given the several uncertainties involved, agreement was considered satisfactory for all elements closing on average between $95 \%$ and $105 \%$ with standard deviation $<10 \%$ for all samples. This could be obtained for most elements, but not for $\mathrm{Be}, \mathrm{Mo}, \mathrm{W}, \mathrm{Ni}, \mathrm{Cu}, \mathrm{Cd}, \mathrm{Sn}, \mathrm{As}, \mathrm{Sb}$ and $\mathrm{Bi}$, largely associated with clay and Fe-oxyhydroxides, potentially affected by anthropogenic pollution (Viers et al., 2009), and whose content in several minerals is poorly determined. Our estimates, briefly summarized below, are provided in full in Appendix $C$ in the Supplementary material.

The chemical budget of surface load is dominated by phyllosilicates, including clay minerals and associated oxyhydroxides, which provide most of $\mathrm{Al}, \mathrm{Fe}, \mathrm{Mg}, \mathrm{K}, \mathrm{Ti}, \mathrm{Mn}, \mathrm{Rb}, \mathrm{Cs}, \mathrm{Be}, \mathrm{Ba}, \mathrm{V}, \mathrm{Nb}, \mathrm{Cr}$, Mo, W, Co, $\mathrm{Ni}, \mathrm{Cu}, \mathrm{Zn}, \mathrm{Cd}, \mathrm{Ga}, \mathrm{Sn}, \mathrm{Pb}, \mathrm{As}, \mathrm{Sb}, \mathrm{Bi}$, half of P, Sc, Y, REE, Th, U, Zr, Hf, Ta, much of $\mathrm{Si}$, and subordinate $\mathrm{Na}, \mathrm{Ca}$, and $\mathrm{Sr}$. Relative contributions of quartz ( 40\% Si in surface load, $60-70 \% \mathrm{Si}$ in deep load), of feldspars (most of $\mathrm{Na}$, half of $\mathrm{Sr}$, significant proportions of $\mathrm{Si}, \mathrm{Al}, \mathrm{Ca}, \mathrm{K}, \mathrm{Rb}, \mathrm{Ba}, \mathrm{Eu}$, $\mathrm{Ga}$, and $\mathrm{Pb}$ ), of carbonates (most of $\mathrm{Ca}$ and significant Mg in Ganga load), and particularly of heavy minerals increase with depth.

Most common heavy-mineral groups are not abundant enough to contribute the majority of any chemical element. Amphibole (Fe, Mg, $\mathrm{Ca}, \mathrm{Mn}, \mathrm{Sc}, \mathrm{MREE}, \mathrm{V}, \mathrm{Cr}, \mathrm{Co}, \mathrm{Ni}$, and $\mathrm{Zn}$ ) and epidote contributions (Ca, Sr, Sc, Y, Eu, HREE, and V) are higher for the Brahmaputra; garnet contributions (much Mn, significant Y, and HREE) are higher for the Ganga. The impact of rare species hosting trace elements in extreme concentrations is more evident. Zircon contributes most of $\mathrm{Zr}$ and $\mathrm{Hf}$, and significant proportions of $\mathrm{Yb}, \mathrm{Lu}, \mathrm{U}$, and Ta. Monazite and allanite together contribute much of LREE and Th and significant MREE and U; xenotime significant Y, HREE, and $\mathrm{U}$; apatite half of $\mathrm{P}$, minor $\mathrm{Ca}$, and MREE. Titanite contributes Ti, MREE, Nb and Ta; rutile Ti, Nb and Ta; and opaque $\mathrm{Fe}-\mathrm{Ti}-\mathrm{Cr}$ oxides $\mathrm{Fe}, \mathrm{Ti}, \mathrm{V}, \mathrm{Nb}, \mathrm{Ta}$ and $\mathrm{Cr}$. Undetected ultradense rare minerals such as cassiterite (Huizing, 1971), wolframite, scheelite, or sulfides (e.g., sphalerite or arsenopyrite, which are relatively stable in oxygenated fluvial environments) may contribute transition metals and other trace elements, as suggested by peak abundances of W, Cd, and $\mathrm{Sn}$ in deepest suspended load above heavy-mineral-enriched bedload.

\section{Modeling suspension sorting}

During transport in a turbulent river flow, detrital grains are partitioned at different depths in the water column according to their settling velocity, which depends on their size, density and shape (Brush, 1965; "suspension sorting" of Slingerland, 1984). Sediments traveling at different depths are eventually deposited in different environments. Finer, less-dense or platier grains carried in suspension may overspill levees during floods, whereas coarser, denser, and more spherical grains entrained as bedload end up in channel lags or bars. Sand reaching the estuary may settle in distributary channels, while mud is flushed offshore (Stummeyer et al., 2002). In order to improve our understanding of fluvial sedimentology, we must thus investigate and quantify the relationships among hydrodynamic conditions, sediment concentration, textural features, and mineralogical and chemical composition of suspended sediment in transit.

\subsection{Suspended-load transport by turbulent diffusion}

Suspended-load transport by turbulent diffusion is well known and experimentally documented (Vanoni, 2006). Sediment concentration $C$ of any detrital component with settling velocity $v$ at a height $h$ above the river bed is (Rouse, 1937):

$C / C_{r}=\left((H-h) /\left(H-h_{r}\right) \cdot h_{r} / h\right)^{v / U}$

where $\mathrm{U}=\mathrm{u}^{*} \cdot \mathrm{k} \cdot \beta . C_{r}$ is the known concentration of the detrital component at a reference level chosen at a small distance $h_{r}$ above the bed, $H$ is river depth, $u^{*}$ the shear velocity, $k$ the von Karman constant, and $\beta$ usually assumed to be 1 (i.e., no movement of the sedimentary particle relative to the particle of fluid which contains it; Briggs and Middleton, 1965). However, $k$ has been shown to decrease from $\sim 0.4$ for clear waters to $\sim 0.2$ for extreme sediment concentrations (Vanoni, 2006), and $\beta$ to be an increasing function of the particle settling velocity (Nielsen and Teakle, 2004).

Eq. (5) predicts that fast-settling grains are markedly concentrated close to the bed, whereas tiny clay flakes are distributed almost uniformly through the water column. For any two minerals $m_{1}$ and $m_{2}$, from Eq. (5) we obtain (Slingerland, 1984):

$C_{m 1} / C_{m 1 r}=\left(C_{m 2} / C_{m 2 r}\right)^{v_{m 1} / v_{m 2}}$.

If known at the reference level, the ratio between the concentrations of any two minerals $m_{1}$ and $m_{2}$ can be determined at any depth:

$C_{m 1} / C_{m 2}=C_{m 1 r} / C_{m 2 r} \cdot\left((H-h) /\left(H-h_{r}\right) \cdot h_{r} / h\right)^{\left(v_{m 1}-v_{m 2}\right) / U}$.

\subsection{Modeling sediment concentrations and textural mixtures}

In the simplest way, suspension sorting can be modeled by considering only the different grain size of clay, silt, and sand modes. Absolute and relative concentrations for each mode at any depth can be predicted by Eq. (5), if known at a reference level of known depth and height above the river bed, and if shear and settling velocities are known. Vice-versa, shear velocity can be estimated with best-fit calculations if concentrations are known at various depths and settling velocities assessed by Eqs. (2) and (3).

In our analysis, sediment-concentration data from 7 vertical profiles ( 3 for Ganga and Brahmaputra, 1 for Meghna) were studied in detail; 73 samples were considered overall (data after Galy et al. (2007)). Settling velocities were assumed to be $<0.0002 \mathrm{~cm} / \mathrm{s}$ for the clay mode (grain size $<2 \mu \mathrm{m}, \mathrm{CSF} 0.1$ ), $0.02 \pm 0.01 \mathrm{~cm} / \mathrm{s}$ for the silt mode (grain size $10-20 \mu \mathrm{m}, \mathrm{CSF} 0.45$ ), and $0.6 \pm 0.2 \mathrm{~cm} / \mathrm{s}$ for the sand mode (grain size $75-110 \mu \mathrm{m}$, CSF 0.7 ).

Best fit calculations gave shear velocities decreasing from Brahmaputra $(U=1.3 \pm 0.6)$ to Ganga $(U=1.0 \pm 0.2)$ and Meghna profiles $(U=0.7)$. Predicted and observed absolute and relative concentrations of each mode at any depth compare closely for all Ganga profiles, and less perfectly for Brahmaputra profiles, which show more irregular trends (Fig. 9). Predicted concentrations at shallow depths are too high for the Meghna profile. Discrepancies in both absolute (mostly $\leq 30 \%$; $<1 \mathrm{~g} / \mathrm{l}$ ) and relative concentrations (mostly $\leq 10 \%$ for sand and silt modes, $\leq 1 \%$ for clay mode) are tolerable for virtually all samples. We judge these results as satisfactory, considering that samples along 

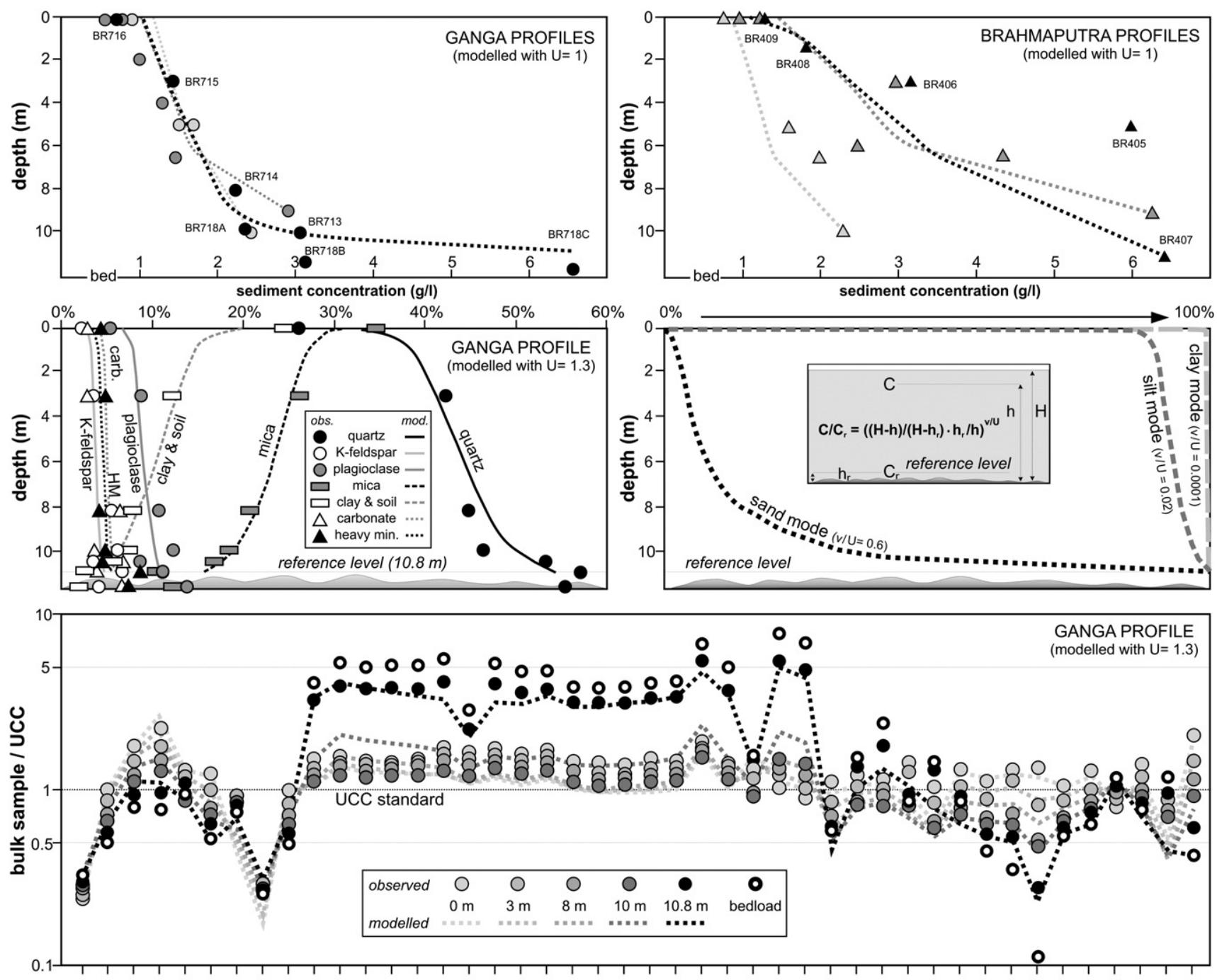

$\mathrm{Na} \mathrm{K} \mathrm{Rb} \mathrm{Cs} \mathrm{Be} \mathrm{Mg} \mathrm{Ca} \mathrm{Sr} \mathrm{Ba} \mathrm{Y} \mathrm{La} \mathrm{Ce} \mathrm{Pr} \mathrm{Nd} \mathrm{Sm} \mathrm{Eu} \mathrm{Gd} \mathrm{Tb} \mathrm{Dy} \mathrm{Ho} \mathrm{Er} \mathrm{Tm} \mathrm{Yb} \mathrm{Lu} \mathrm{Th} \mathrm{U} \mathrm{Ti} \mathrm{Zr} \mathrm{Hf} \mathrm{V} \mathrm{Nb} \mathrm{Ta} \mathrm{Cr} \mathrm{Mn} \mathrm{Fe} \mathrm{Co} \mathrm{Ni} \mathrm{Cu} \mathrm{Al} \mathrm{Ga} \mathrm{Si} \mathrm{Pb} \mathrm{P} \mathrm{As}$

Fig. 9. Modeling concentration, mineralogy and geochemistry of suspended load (elements in multielement diagram normalized to UCC). For all three Ganga and three Brahmaputra profiles, absolute and relative concentrations of sand, silt and clay modes are satisfactorily predicted by Rouse equation with $U \approx 1$ (shear velocities $2.5-3.3 \mathrm{~cm} / \mathrm{s}$ for $0.4 \leq \beta \cdot k \leq 0.3$ ). The best fit for mineralogical and chemical composition through Ganga profile BR716/BR718C is obtained with $U=1.3$ (shear velocity $3.2-4.3 \mathrm{~cm} / \mathrm{s}$ for $0.4 \leq \beta \cdot k \leq 0.3$ ). REE concentration is reproduced faithfully close to reference level (BR718C), but not for shallower load, where model predicts progressive REE decrease contrary to observation.

ideally vertical profiles were in fact collected at intervals of tens of minutes and horizontal distances of tens of metres, while hydrodynamic conditions were varying irregularly in space and time. Moreover, channel depth could seldom be determined with sufficient precision, which has substantial impact on model results.

We also attempted to integrate all 73 samples in one ideally complete vertical profile. Assuming a total concentration of $6.5 \mathrm{~g} / \mathrm{l}$ of sediment including $83 \%$ sand mode, $16 \%$ silt mode, and $1 \%$ clay mode at $11.5 \mathrm{~m}$ depth, $0.5 \mathrm{~m}$ above the channel bed, the best fit is obtained for $U=0.98$. Estimated shear velocity $(2.5-3.3 \mathrm{~cm} / \mathrm{s}$ for $0.4 \leq \beta \cdot k \leq 0.3)$ is only slightly greater than estimated settling velocity of upperfine-sand-sized bedload $(2.0-2.5 \mathrm{~cm} / \mathrm{s})$, thus supporting Middleton's (1976) postulate that shear velocity during dominant discharge needs to be close to bedload settling velocity, slower-settling grains being lifted into suspension. Predicted total sediment concentration for surface load is $0.8 \mathrm{~g} / \mathrm{l}$, including $95 \%$ silt mode and $5 \%$ clay mode.

\subsection{Modeling mineralogical and chemical variability}

The absolute and relative concentration of each detrital component at any depth and in each size class can be predicted with a standard spreadsheet, if size distribution, mineralogy and concentration of sand, silt, and clay modes are known at the reference level (Fig. 9). Settling velocities were calculated by Eq. (3), reduced by one third for phyllosilicates in order to account for their platy shape. Discrepancies between observations and model predictions ( $\leq 10 \%$ for grain size, $\leq 20 \%$ for total concentration, mostly $\leq 30 \%$ for tectosilicates, carbonates, phyllosilicates, and most common heavy-mineral groups) are not much higher than determination error for each detrital component. If size distribution is assumed as lognormal at the reference level, the model predicts that each mode and single detrital component is progressively better sorted and positively skewed in shallower load because of progressive truncation of the coarse tail, which contradicts observation.

By converting mineralogical (weight percentages) into chemical composition, the suspension-sorting model can predict chemical composition at any depth and for any size class (Fig. 9). The model proved to be particularly helpful to evaluate the incidence of the many imprecisely known textural, mineralogical, chemical and physical variables involved, and to check their overall consistency.

\section{Conclusion}

The mineralogy of suspended-load silt, a fundamental component of sediment transport, cannot be determined in full detail with 
traditional optical or X-ray-diffraction methods. In this study, mineralogical data accurate and precise enough to allow comparison with chemical data and to test settling-equivalence and suspensionsorting models were obtained by the extensive use of Raman spectroscopy, supplemented by optical heavy-mineral analyses of classes coarser than fine silt and XRD analyses of finer-grained mud. By systematically coupling sediment-concentration, textural, mineralogical, and geochemical data, we could thus investigate intersample and intrasample variability in the largest sedimentary system on Earth.

Compositional variability of suspended load is primarily controlled by hydraulic-sorting effects, superposed on provenance, weathering, and anthropic effects. Sediment in suspension is a mixture of clay with associated Fe-oxyhydroxides and organic matter, poorly-sorted silt rich in phyllosilicates and soil aggregates, and moderately-sorted very-fine sand. Regular textural, mineralogical and consequently geochemical trends through the water column result from virtually invariant absolute concentration of clay and relatively uniform distribution of slow-settling tiny phyllosilicates, whereas fast-settling coarser, denser, and more spherical grains markedly concentrate toward the river bed. Such trends can be modeled with classical formulas describing sediment transport by turbulent diffusion. Best fit calculations allowed us to assess contributions by each mineral to the chemical budget, and to calibrate dense and ultradense minerals too rare to be precisely estimated by optical, XRD or Raman analysis but crucial in both detrital-geochronology and settling-equivalence studies. Hydrodynamic conditions during dominant monsoonal discharge could also be evaluated.

Quantitative mineralogical analysis of silt-sized sediments by innovative techniques such as Raman spectroscopy opens up new frontiers in sedimentary petrology. Provenance information can thus be extracted from mudrocks, which represent a very conspicuous part of the stratigraphical record and are prone to preserve original detrital assemblages from diagenetic dissolution better than permeable interlayered sandstones. Scrutiny of mineralogical and chemical variability in an active fluviodeltaic system allows us to constrain how and to what extent sediment composition is modified physically and chemically during transfer from detrital sources to depositional sinks, a fundamental requisite to make accurate provenance diagnoses and sediment budgets. Unraveling mineralogical fractionation in deltaic environments is specifically needed to compare the composition of fluvial and turbiditic deposits, and thus to unambiguously trace detrital signatures from mountain belts to ocean floors. Practical applications of economic interest include a better understanding of sediment transport needed for quality management of fluvial catchments, and an improved determination of detrital fluxes for correct assessment of soil erosion, lifetime of reservoirs, anthropogenic pollution and sustainable land use in heavily populated areas.

\section{Acknowledgments}

The article benefited from reviews by R.L. Cullers and two anonymous reviewers. Contributions by A. Paleari, D. Bersani, L. Borromeo (Raman analyses), M. Setti, L. Marinoni, M. Dapiaggi, V. Barberini (XRD analyses), C. Pasquero and J. Lavé (physical aspects) were greatly appreciated. CFL and VG were supported by INSU-CNRS program "Reliefs de la Terre". Prof. M. Rahman (Dhaka University) is warmly thanked for invaluable help in Bangladesh.

\section{Appendices A, B, C, and D Supplementary data}

Supplementary data to this article can be found online at doi:10.1016/ j.epsl.2010.11.043.

\section{References}

Allison, M.A., Khan, S.R., Goodbred, S.L., Kuehl, S.A., 2003. Stratigraphic evolution of the late Holocene Ganges-Brahmaputra lower delta plain. Sedim. Geol. 155, 317-342. Ashley, G.M., 1978. Interpretation of polymodal sediments. J. Geol. 86, 411-421.

Attal, M., Lavé, J., 2006. Changes of bedload characteristics along the Marsyandi River (central Nepal): implications for understanding hillslope sediment supply, sediment load evolution along fluvial networks, and denudation in active orogenic belts. Geol. Soc. Am. Spec. Pap. 398, 143-171.

Baba, J., Komar, P.D., 1981. Measurements and analysis of settling velocities of natural quartz sand grains. J. Sedim. Petrol. 51, 631-640.

Bea, F., 1996. Residence of REE, Y, Th and $U$ in granites and crustal protoliths; implications for the chemistry of crustal melts. J. Petrol. 35, 521-552.

Best, J.L., Ashworth, P.J., Sarker, M.H., Roden, J.E., 2007. The Brahmaputra-Jamuna River, Bangladesh. In: Gupta, A. (Ed.), Large Rivers: Geomorphology and Management. Wiley, Chichester, pp. 395-433.

Blatt, H., 1985. Provenance studies and mudrocks. J. Sedim. Res. 55, 69-75.

Blatt, H., Jones, R.L., 1975. Proportions of exposed igneous, metamorphic, and sedimentary rocks. Geol. Soc. Am. Bull. 86, 1085-1088.

Blatt, H., Sutherland, B., 1969. Intrastratal solution and non-opaque heavy minerals in mudrocks. J. Sedim. Petrol. 39, 591-600.

Borges, J., Huh, Y., 2007. Petrography and chemistry of the bed sediments of the Red River in China and Vietnam: provenance and chemical weathering. Sediment. Geol. 194, 155-168.

Briggs, L.I., Middleton, G.V., 1965. Hydromechanical principles of sediment structure formation. In: Middleton, G.V. (Ed.), Primary Sedimentary Structures and Their Hydrodynamic Interpretations: S.E.P.M. Spec. Publ., 12, pp. 5-16.

Briggs, L.I., McCulloch, D.S., Moser, F., 1962. The hydraulic shape of sand particles. J. Sedim. Petrol. 32, 645-656.

Brush, L.M., 1965. Sediment sorting in alluvial channels. In: Middleton, G.V. (Ed.), Primary Sedimentary Structures and Their Hydrodynamic Interpretation: Soc. Econ. Paleont. Miner. Spec. Publ., 12, pp. 25-33.

Carignan, J., Hild, P., Mevelle, G., Morel, J., Yeghicheyan, D., 2001. Routine analyses of trace element in geological samples using flow injection and low pressure on-line liquid chromatography coupled to ICP-MS: a study of geochemical reference materials BR, DR-N, UB-N, AN-G and GH. Geostandards Newsletter 25, 187-198.

Cheng, N.-S., 1997. Simplified settling velocity formula for sediment particle. J. Hydraulic Engrg. 123, 149-152.

Clark, M.W., 1976. Statistical analysis of multimodal distributions. J. Math. Geol. 8, 267-282.

Condie, K.C., 1993. Chemical composition and evolution of the upper continental crust: contrasting results from surface samples and shales. Chem. Geol. 104, 1-37.

Cullers, R.L., 1988. Mineralogical and chemical changes of soil and stream sediment formed by intense weathering of the Danburg granite, Georgia, U.S.A. Lithos 21, 301-314.

Cullers, R.L., 1995. The controls on the major- and trace-element evolution of shales, siltstones and sandstones of Ordovician to Tertiary age in the Wet Mountains region, Colorado, U.S.A. Chem. Geol. 123, 107-131.

Curray, J.R., Emmel, F.J., Moore, D.G., 2003. The Bengal Fan: morphology, geometry, stratigraphy, history and processes. Marine Petrol. Geol. 19, 1191-1223.

Datta, D.K., Subramanian, V., 1997. Texture and mineralogy of sediments from the Ganges-Brahmaputra-Meghna river system in the Bengal Basin, Bangladesh, and their environmental implications. Environ. Geol. 30, 181-188.

Datta, D.K., Subramanian, V., 1998. Distribution and fractionation of heavy metals in the surface sediments of the Ganges-Brahmaputra-Meghna river system in the Bengal basin. Environm. Geol. 36, 93-101.

Degueldre, C., Kline, A., 2007. Study of thorium association and surface precipitation on colloids. Earth Planet. Sci. Lett. 264, 104-113.

Dickinson, W.R., 2008. Impact of differential zircon fertility of granitoid basement rocks in North America on age populations of detrital zircons and implications for granite petrogenesis. Earth Planet. Sci. Lett. 275, 80-92.

Dickinson, W.R., Suczek, C.A., 1979. Plate tectonics and sandstone composition. Am. Assoc. Pet. Geol. Bull. 63, 2164-2172.

Dietrich, W.E., 1982. Settling velocity of natural particles. Water Resources Res. 18, $1615-1626$

Doyle, L.J., Carder, K.L., Steward, R.G., 1983. The hydraulic equivalence of mica. J. Sedim. Petrol. 53, 643-648.

Duzgoren-Aydin, N.S., Aydin, A., Malpas, J., 2002. Reassessment of chemical weathering indices: case study on pyroclastic rocks of Hong Kong. Eng. Geol. 63, 99-119.

France-Lanord, C., Derry, L., Michard, A., 1993. Evolution of the Himalaya since Miocene time: isotopic and sedimentological evidence from the Bengal Fan. In: Treloar, P.J., Searle, M.P. (Eds.), Himalayan Tectonics: Geol. Soc. London Spec. Publ., 74, pp. 603-622.

Galy, A., France-Lanord, C., 1999. Weathering processes in the Ganges-Brahmaputra basin and the riverine alkalinity budget. Chem. Geol. 159, 31-60.

Galy, V., France-Lanord, C., Beyssac, O., Faure, P., Kudrass, H., Palhol, F., 2007. Efficient organic carbon burial in the Bengal fan sustained by the Himalayan erosional system. Nature $450,407-410$

Gansser, A., 1964. Geology of the Himalayas. Wiley, New York. 289 pp.

Garzanti, E., Andò, S., 2007. Heavy-mineral concentration in modern sands: implications for provenance interpretation. In: Mange, M.A., Wright, D.T. (Eds.), Heavy Minerals in Use. : Developments in Sedimentology Series, 58. Elsevier, Amsterdam, pp. 517-545.

Garzanti, E., Vezzoli, G., Andò, S., France-Lanord, C., Singh, S.K., Foster, G., 2004. Sand petrology and focused erosion in collision orogens: the Brahmaputra case. Earth Planet. Sci. Lett. 220, 157-174. 
Garzanti, E., Doglioni, C., Vezzoli, G., Andò, S., 2007a. Orogenic belts and orogenic sediment provenances. J. Geol. 115, 315-334.

Garzanti, E., Vezzoli, G., Andò, S., Lavé, J., Attal, M., France-Lanord, C., DeCelles, P., 2007b. Quantifying sand provenance and erosion (Marsyandi River, Nepal Himalaya). Earth Planet. Sci. Lett. 258, 500-515.

Garzanti, E., Andò, S., Vezzoli, G., 2008. Settling-equivalence of detrital minerals and grainsize dependence of sediment composition. Earth Planet. Sci. Lett. 273, 138-151.

Garzanti, E., Ando', S., Vezzoli, G., 2009. Grain-size dependence of sedimen composition and environmental bias in provenance studies. Earth Planet. Sci. Lett. 277, 422-432.

Garzanti, E., Andò, S., France-Lanord, C., Vezzoli, G., Galy, V., Najman, Y., 2010 Mineralogical and chemical variability of fluvial sediments. 1. Bedload sand (Ganga-Brahmaputra, Bangladesh). Earth Planet. Sci. Lett. 299, 368-381.

Goodbred, S.L., Kuehl, S.A., 2000. Enormous Ganges-Brahmaputra sediment discharge during strengthened early Holocene monsoon. Geology 28, 1083-1086.

Govindaraju, K., Mevelle, G., 1987. Fully automated dissolution and separation methods for inductively coupled plasma-atomic emission spectrometry rock analysis. Application to the determination of rare earth elements. J. Analytical Atomic Spectrometry 2, 615-621.

Haley, B.A., Klinkhammer, G.P., McManus, J., 2004. Rare earth elements in pore water of marine sediments. Geochim. Cosmochim. Acta 68, 1265-1279.

Hay, W.W., 1998. Detrital sediment fluxes from continents to oceans. Chem. Geol. 145 287-323.

Heroy, D.C., Kuehl, S.A., Goodbred, S.L., 2003. Mineralogy of the Ganges and Brahmaputra Rivers: implications for river switching and Late Quaternary climate change. Sedim. Geol. 155, 343-359.

Hu, Z., Gao, S., 2008. Upper crustal abundances of trace elements: a revision and update Chem. Geol. 253, 205-221.

Huizing. H.G.J. 1971. A reconnaissance study of the mineralogy of sand fractions from East Pakistan sediments and soils. Geoderma 6, 109-133.

Ingersoll, R.V., 1990. Actualistic sandstone petrofacies: discriminating modern and ancient source rocks. Geology 18, 733-736.

Islam, A.K.M.E., Lotse, E.G., 1986. Quantitative mineralogical analysis of some Bangladesh soils with X-ray, ion exchange and selective dissolution techniques. Clay Miner. 21, 31-42.

Islam, M.R., Begum, S.F., Yamaguchi, Y., Ogawa, K., 1999. The Ganges and Brahmaputra rivers in Bangladesh: basin denudation and sedimentation. Hydrol. Proces. 13, 2907-2923.

Komar, P.D., Reimers, C.E., 1978. Grain shape effects on settling rates. J. Geol. 86, 193-209.

Komar, P.D., Baba, J., Cui, B., 1984. Grain-size analyses of mica within sediments and the hydraulic equivalence of mica and quartz. J. Sedim. Petrol. 54, 1379-1391.

Le Roux, J.P., 2005. Grains in motion: a review. Sedim. Geol. 178, 285-313.

Malusà, M.G., Zattin, M., Andò, S., Garzanti, E., Vezzoli, G., 2009. Focused erosion in the Alps constrained by fission-track ages on detrital apatites. In: Lisker, F., Ventura, B. Glasmacher, U.A. (Eds.), Thermochronological Methods: From Palaeotemperature Constraints to Landscape Evolution Models: Geol. Soc. London Spec. Publ., 324, pp. $141-152$.

McDonough, W.F., Sun, S.S., 1995. The composition of the Earth. Chem. Geol. 120, 223-253.

McLennan, S.M., 1989. Rare earth elements in sedimentary rocks: influence of provenance and sedimentary processes. Rev. Mineral. Geochem. 21, 169-200.

McLennan, S.M., 2001. Relationships between the trace element composition of sedimentary rocks and upper continental crust. Geochem. Geophys. Geosyst. 2. doi:10.1029/2000GC000109.

Middleton, G.V., 1976. Hydraulic interpretation of sand size distributions. J. Geol. 84, 405-426.

Milliman, J.D., Meade, R.H., 1983. World delivery of river sediment to the oceans. J. Geol. $91,1-21$

Moecher, D.P., Samson, S.D., 2006. Differential zircon fertility of source terranes and natural bias in the detrital zircon record: implications for sedimentary provenance analysis. Earth Planet. Sci. Lett. 247, 252-266.

Mongelli, G., Critelli, S., Perri, F., Sonnino, M., Perrone, V., 2006. Sedimentary recycling provenance and paleoweathering from chemistry and mineralogy of Mesozoi continental redbed mudrocks, Peloritani mountains, southern Italy. Geochem. J. 40, 197-209.

Moore, D.M., Reynolds, R.C., 1989. X-ray Diffraction and the Identification and Analysis of Clay Minerals. Oxford Univ, Press, New York. 332 pp.

Nesbitt, H.W., Young, G.M., 1982. Early Proterozoic climates and plate motions inferred from major element chemistry of lutites. Nature 299, 715-717.

Nielsen, P., Teakle, I.A.L., 2004. Turbulent diffusion of momentum and suspended particles: a finite-mixing-length theory. Phys. Fluids 16, 2342-2348.

Parker, A., 1970. An index of weathering for silicate rocks. Geol. Mag. 107, 501-504.

Poppe, L.J., Commeau, J.A., 1996. Silt heavy-mineral distributions off the Southeastern United States. Geo-Marine Lett. 16, 115-122.

Potter, P.E., 1978. Petrology and chemistry of modern big river sands. J. Geol. 86, $423-449$

Price, J.R., Velbel, M.A., 2003. Chemical weathering indices applied to weathering profiles developed on heterogeneous felsic metamorphic parent rocks. Chem. Geol. 202, 397-416.

Quinn, K.A., Byrne, R.H., Schijf, J., 2006. Sorption of yttrium and rare earth elements by amorphous ferric hydroxide: influence of $\mathrm{pH}$ and ionic strength. Marine Chem. 99, 128-150.
Ramesh, R., Ramanathan, A., Ramesh, S., Purvaja, R., Subramanian, V., 2000. Distribution of rare earth elements and heavy metals in the surficial sediments of the Himalayan river system. Geochem. J. 34, 295-319.

Rittenhouse, G., 1943. Transportation and deposition of heavy minerals. Geol. Soc. Am. Bull. 54, 1725-1780.

Rouse, $\mathrm{H}$. 1937. Modern conceptions of the mechanics of fluid turbulence. Trans. Am. Soc. Civ. Eng. 102 (paper $n^{\circ} 1965$ ), 463-543.

RSP (River Survey Project), 1996. Spatial representation and analysis of hydraulic and morphological data. Report no. FAP 24. WARPO, Dhaka, Bangladesh.

Rubatto, D., 2002. Zircon trace element geochemistry: partitioning with garnet and the link between U-Pb ages and metamorphism. Chem. Geol. 184, 123-138.

Rubey, W.W., 1933. The size-distribution of heavy minerals within a water-laid sandstone. J. Sedim. Petrol. 3, 3-29.

Sarin, M.M., Krishnaswami, S., Dilli, K., Somayajulu, B.L.K., Moore, W.S., 1989. Major ion chemistry of the Ganga-Brahmaputra river system: weathering processes and fluxes to the Bay of Bengal. Geochim. Cosmochim. Acta 53, 997-1009.

Schieber, J., Zimmerle, W., 1998. Petrography of shales: a survey of techniques. In: Schieber, J., Zimmerle, W., Sethi, P. (Eds.), Shales and Mudstones. : Petrography, Petrophysics, Geochemistry, and Economic Geology, vol. II. Schweizerbart, Stuttgart, pp. 3-12.

Schuiling, R.D., de Meijer, R.J., Riezebos, H.J., Scholten, M.J., 1985. Grain size distribution of different minerals in a sediment as a function of their specific density. Geologie en Mijnbow 64, 199-203.

Shamsudduha, M., Uddin, A., Saunders, J.A., Lee, M.-K, 2008. Quaternary stratigraphy, sediment characteristics and geochemistry of arsenic-contaminated alluvial aquifers in the Ganges-Brahmaputra floodplain in central Bangladesh. J. Contaminant Hydrol. 99, 112-136.

Singh, I.B., 2007a. The Ganga River. In: Gupta, A. (Ed.), Large Rivers: Geomorphology and Management. Wiley, Chichester, pp. 347-371.

Singh, S.K., 2007b. Erosion and weathering in the Brahmaputra River system. In: Gupta, A. (Ed.), Large Rivers: Geomorphology and Management. Wiley, Chichester, pp. 373-393.

Singh, S.K., France-Lanord, C., 2002. Tracing the distribution of erosion in the Brahmaputra watershed from isotopic compositions of stream sediments. Earth Planet. Sci. Lett. 202, 645-662.

Singh, M., Müller, G., Singh, I.B., 2002. Heavy metals in freshly deposited stream sediments of rivers associated with urbanisation of the Ganga Plain, India. Wate Air Soil Pollut. 141, 35-54.

Singh, S.K., Sarin, M.M., France-Lanord, C., 2005. Chemical erosion in the eastern Himalaya: major ion composition of the Brahmaputra and $\delta^{13} \mathrm{C}$ of dissolved inorganic carbon. Geochim. Cosmochim. Acta 69, 3573-3588.

Slingerland, R., 1984. Role of hydraulic sorting in the origin of fluvial placers. J. Sedim. Petrol. 54, 137-150.

Spear, F.S., Pyle, J.M., 2002. Apatite, monazite, and xenotime in metamorphic rocks. In Kohn, M.L., Rakovan, J., Hughes, J.M. (Eds.), Phosphates. Geochemical, Geobiological, and Materials Importance: Reviews in Mineralogy and Geochemistry, 48, pp. 293-335.

Stummeyer, J., Marchig, V., Knabe, W., 2002. The composition of suspended matter from Ganges-Brahmaputra sediment dispersal system during low sediment transport season. Chem. Geol. 185, 125-147.

Summerfield, M.A., Hulton, N.J., 1994. Natural controls of fluvial denudation rates in major world drainage basins. J. Geophys. Res. 99, 13871-13883.

Sun, D., Bloemendal, J., Rea, D.K., Vandenberghe, J., Jiang, F., An, Z., Su, R., 2002. Grainsize distribution function of polymodal sediments in hydraulic and aeolian environments, and numerical partitioning of the sedimentary components. Sedim. Geol. 152, 263-277.

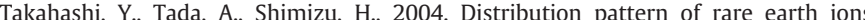
between water and montmorillonite and its relation to the sorbed species of the ions. Analytical Sci. 20, 1301-1306.

Tanner, W.F., 1964. Modification of sediment size distributions. J. Sedim. Petrol. 34 $156-164$.

Taylor, S.R., McLennan, S.M., 1985. The Continental Crust: Its Composition and Evolution. Blackwell Scientific, Boston. 312 p.

Taylor, S.R., McLennan, S.M., 1995. The geochemical evolution of the continental crust. Rev. Geophys. 33, 241-265.

Totten, M.W., Hanan, M.A., 2007. Heavy minerals in shales. In: Mange, M.A., Wright, D.T. (Eds.), Heavy Minerals in Use. : Developments in Sedimentology Series, 58. Elsevier, Amsterdam, pp. 323-341.

Valloni, R., Maynard, J.B., 1981. Detrital modes of recent deep-sea sands and their relation to tectonic setting: a first approximation. Sedimentology 28, 75-83.

Vanoni, V.A., 2006. Sedimentation engineering. Am. Soc. Civ. Eng., Reston: ASCE Manuals and Reports in Engineering Practice, 54. 418 p.

Viers, J., Dupré, B., Gaillardet, J., 2009. Chemical composition of suspended sediments in World Rivers: new insights from a new database. Sci. Total Environm. 407 853-868.

Webster, J.R., Kight, R.P., Winburn, R.S. Cool, C.A., 2003. Heavy mineral analysis of sandstones by Rietveld analysis. Adv. X-Ray Anal. 46, 198-203.

Yokohama, K., Amano, K., Taira, A., Saito, Y., 1990. Mineralogy of silts from the Bengal Fan. In: Cochran, J.R., Stow, D.A.V. (Eds.), Proc. ODP Program Sci. Res. 116, 59-73.

Zuffa, G.G. 1985. Provenance of arenites. Reidel, Dordrecht, NATO-ASI Series, 148, p. 408. 